OPEN ACCESS

Edited by: John L. Provis,

University of Sheffield

United Kingdom

Reviewed by:

Ali Behnood,

Purdue University, United States

Dimitri Feys,

Missouri University of Science and

Technology, United States

*Correspondence:

Paulo H. R. Borges

Paulo.borges@cefetmg.br

Specialty section:

This article was submitted to

Structural Materials,

a section of the journal

Frontiers in Materials

Received: 01 December 2018

Accepted: 05 April 2019

Published: 07 May 2019

Citation:

Batista RP, Trindade ACC, Borges PHR and Silva FA (2019) Silica Fume as Precursor in the Development of Sustainable and High-Performance MK-Based Alkali-Activated Materials Reinforced With Short PVA Fibers. Front. Mater. 6:77.

doi: 10.3389/fmats.2019.00077

\section{Silica Fume as Precursor in the Development of Sustainable and High-Performance MK-Based Alkali-Activated Materials Reinforced With Short PVA Fibers}

\author{
Raquel P. Batista ${ }^{1}$, Ana Carolina C. Trindade ${ }^{2}$, Paulo H. R. Borges ${ }^{1 *}$ and Flávio de A. Silva ${ }^{2}$ \\ ${ }^{1}$ Department of Civil Engineering, Centro Federal de Educação Tecnológica de Minas Gerais (CEFET-MG), Belo Horizonte, \\ Brazil, ${ }^{2}$ Department of Civil and Environmental Engineering, Pontifical Catholic University of Rio de Janeiro (PUC-RIO), Rio de \\ Janeiro, Brazil
}

Alkali-activated materials (AAM) are currently the subject of increasing interest and research, mainly due to the possibility of reducing the carbon dioxide $\left(\mathrm{CO}_{2}\right)$ emissions in their production when compared to Portland cement (PC) and still achieve superior performance in many aspects when compared to traditional PC-based products. However, the use of sodium silicate (SS) as an alkaline activator in AAM is controversial when the aim is to reduce the environmental impact, as the production of the first also releases significant amount of $\mathrm{CO}_{2}$ per ton of activator produced. Therefore, a demand has emerged for alternative silica-rich materials that could effectively reduce the demand for SS without compromising the mechanical behavior of the matrices and consequently the performance of fiber reinforced AAM. This paper investigates the gradual replacement (0-18\% wt.) of metakaolin (MK) with silica fume (SF) in PVA-reinforced AAM, allowing the reduction of SS in the activator, also containing $\mathrm{NaOH}$. Matrices with different composition were studied, i.e., with $\left[\mathrm{SiO}_{2}\right] /\left[\mathrm{Al}_{2} \mathrm{O}_{3}\right]$ molar ratios of 3.0 and 3.8. All formulations were reinforced with $2 \%$ vol. of PVA fibers. The mechanical properties investigated were compressive strength, modulus of elasticity, flexural strength, and toughness. Apparent dry density, water absorption, and porosity of the composites were also assessed to give an indication of their durability. Single fiber pullout, fracture toughness, and direct tensile tests were also carried out in order to understand the deformation capability of the composites. Results indicated that the employment of SF may effectively reduce the demand for SS in the alkaline activators, in order to produce alkali-activated composites with lower environmental impact (reduced $\mathrm{CO}_{2}$ emissions). Adjustments in the formulations may improve toughness in flexion in 170\% with 30 wt.\% reduction of SS in the activator, as well as improvements in deformation capability in tension. The development of strain-hardening MK-based AAM, however, has some challenging aspects that are also discussed.

Keywords: alkali-activated materials, geopolymers, activators, PVA fibers, metakaolin, silica fume 


\section{INTRODUCTION}

The intense energy consumption and the wide emission of carbon dioxide $\left(\mathrm{CO}_{2}\right)$ involved in the production of Portland cement (PC) led to the development of several alternative cements, also known as "green" cements, that have emerged in the last two decades. These binders have been studied with the aim of developing products that require less energy to be produced, release less $\mathrm{CO}_{2}$ into the atmosphere, and that have similar or improved structural properties than those presented by PC products (Stavrinides, 2010; Komnitsas, 2011).

Alkali-activated materials (AAM) are alternative binders to PC that result from reactions between alkaline solution and precursor materials rich in silica and alumina (Lloyd and Rangan, 2010; Van Deventer et al., 2010). In terms of sustainability, the AAM production generate, in average, 0.18 tons of $\mathrm{CO}_{2}$ per ton of binder, which corresponds to a reduction of about $80 \%$ in $\mathrm{CO}_{2}$ emissions when compared to the production of ordinary Portland cement (Stavrinides, 2010; Juenger et al., 2011).

Besides the environmental factor, AAM present several other advantages in comparison to PC-based mortars and concretes, such as fast development of mechanical strength (Duxson et al., 2007), reduced expansion by alkaliaggregate reaction (Davidovits, 1994), higher durability in aggressive environment (Bakharev et al., 2001a,b, 2002, 2003) and higher resistance to elevated temperatures (Kong et al., 2007; Kong and Sanjayan, 2008).

Alkaline activation is a complex process, consisting of several steps that involve a series of dissolution, reorientation, and solidification reactions (Provis et al., 2005). One of the most important factors related to alkali-activated systems is the availability of soluble silica, as it affects workability, hardening and the development of mechanical strength, as well as the modification of the gel composition and the microstructure of the produced material (Garcia-Lodeiro et al., 2015). The soluble silica is only detrimental when employed in high concentrations, with consequent reductions in $\mathrm{pH}$ and an increase in the viscosity of the activating solution, leading to a reduction in the raw material's reaction rate (Duxson et al., 2005).

In this sense, the use of controlled amount of sodium silicate (SS) as an alkaline activator ensures high mechanical strength and low permeability of AAM, since it accelerates the activation reactions by providing silica readily available to react with the precursors. However, the employment of SS has become an issue in the production of AAM due to (i) its high cost in some countries and (ii) the fact that its production cannot be considered environmentally friendly (Bernal et al., 2012; Borges et al., 2014). In fact, the production process of SS involves the calcination of sodium carbonate $\left(\mathrm{Na}_{2} \mathrm{CO}_{3}\right)$ with quartz sand $\left(\mathrm{SiO}_{2}\right)$ at temperatures between 1,400 and $1,500^{\circ} \mathrm{C}$; this process generates $\mathrm{CO}_{2}$ and other emissions related to the fuels used during calcination (Bernal et al., 2012). Thus, a demand has emerged for alternative alkaline activators or silicarich precursors that could effectively reduce the demand of SS in AAM.

Several studies have shown that amorphous silica-rich materials may be used as alternative alkaline activators to produce
AAM (Bernal et al., 2012), such as silica fume (Rouseková et al., 1997; Bajza et al., 1998; Živica, 1999, 2004, 2006; Bernal et al., 2012; Rodríguez et al., 2013), rice husk ash (Bernal et al., 2012; Kamseu et al., 2017), and waste glass (Puertas and TorresCarrasco, 2014; Torres-Carrasco and Puertas, 2015; Tchakouté et al., 2016; Vafaei and Allahverdi, 2017). Those materials may be both economically and environmentally advantageous when compared to commercially available SS solutions.

However, sustainability involves not only the quantification of the environmental impact but also the assurance of high durability and consequently long service life of the structures. The durability of cementitious materials is, among other factors, limited by its inherent brittleness, which leads to cracking of the matrix and facilitates the penetration of deleterious agents. Like PC matrices, AAM are brittle materials that may require fibers to improve the ductile character, which ultimately affects their durability (Sakulich, 2011; Bernal et al., 2014; Komljenović, 2015).

Several types of fibers have already been employed in reinforced AAM. Poly vinyl alcohol (PVA) fibers stand out because of their high stability in alkaline environments and because they are currently employed in the development of highperformance cementitious composites. Recent researches have shown that these fibers may also improve the performance of AAM (Li et al., 2005; Lee et al., 2012; Shaikh, 2013; Nematollahi et al., 2014). Further studies (Bhutta et al., 2016; Borges et al., 2017) indicate that the toughness of PVA reinforced AAM may be a function of the amount of soluble silica in the system. However, this relationship is still not completely understood.

Micromechanical models based on concepts of fracture mechanics and materials deformation mechanisms were created to allow the understanding of the deformation capability mechanism of cementitious composites. Those models meet the increasing demand for materials with higher mechanical performance; they describe the deformation behavior of fiberreinforced cementitious composites by the combination of properties presented by the matrix, the fibers and the fiber-matrix interface. According to Li and Leung (1992), two conditions must be fulfilled for the strain-hardening behavior to occur:

(i) Energy criterion: The maximum complementary energy of the composite $\left(J_{b}^{\prime}\right)\left[J / \mathrm{m}^{2}\right]$, must be greater than the crack tip toughness of the matrix $\left(\mathrm{J}_{\text {tip }}\right)\left[\mathrm{J} / \mathrm{m}^{2}\right]$, that is, $\mathrm{J}_{\text {tip }} \leq \mathrm{J}_{\mathrm{b}}^{\prime}$.

$$
J_{t i p}=\frac{K_{m}^{2}}{E_{m}}
$$

where $K_{m}$ is the matrix fracture toughness $[\mathrm{MPa} \cdot \sqrt{ } \mathrm{m}]$ and $\mathrm{E}_{\mathrm{m}}$ is the matrix Young's modulus [GPa] (Li and Leung, 1992).

(ii) Tension criterion: The matrix resistance to the first crack $\left(\sigma_{\mathrm{cc}}\right)[\mathrm{MPa}]$ cannot exceed the maximum bond stress $\left(\sigma_{\mathrm{o}}\right)$ [MPa] that prevents cracking (i.e., $\sigma_{\mathrm{cc}} \leq \sigma_{\mathrm{o}}$ ).

Based on these criteria, the use of two performance indexes (Pseudo Strain-Hardening index-PSH), related to energy $\left(\mathrm{PSH}_{\text {energy }}\right)$ and tension $\left(\mathrm{PSH}_{\text {tension }}\right)$, has been suggested by Kanda and $\mathrm{Li}$ (2006) to measure the performance of the composites. 
This paper investigates the effects of the source of soluble silica on the mechanical performance and deformation capability of different formulations of alkali-activated mortars reinforced with short PVA fibers. The matrix composition varied due to the replacement of metakaolin (MK) with silica fume (SF), with consequent reduction of the amount of sodium silicate (SS) used in the activator. The results help understand the factors affecting the mechanical performance and the development of high-performance alkali-activated composites.

\section{MATERIALS AND METHODS}

\section{Materials}

MK was supplied by Metacaulim do Brasil ltda.; this was the main precursor material employed in the production of the AAM. The AAM produced with $100 \%$ MK was then used as reference. Other matrices were produced by partially replacing $\mathrm{MK}$ with small quantities of SF, the latter supplied by Tecnosil ltda., Brazil. Differently from $\mathrm{MK}\left(\mathrm{SiO}_{2}=43.55 \%\right.$; $\mathrm{Al}_{2} \mathrm{O}_{3}=37.00 \%$ calculated by XRF), SF ( $\mathrm{SiO}_{2}=93.40 \%$; $\mathrm{Al}_{2} \mathrm{O}_{3}=0.75 \%$ ) contains negligible amounts of $\mathrm{Al}_{2} \mathrm{O}_{3}$ and it is mainly composed of $\mathrm{SiO}_{2}$. Therefore, the addition of SF makes it possible (i) to increase the $\left[\mathrm{SiO}_{2}\right] /\left[\mathrm{Al}_{2} \mathrm{O}_{3}\right]$ molar ratio of the matrices without the need to considerably increase the amount of SS in the activator or (ii) to maintain the $\left[\mathrm{SiO}_{2}\right] /\left[\mathrm{Al}_{2} \mathrm{O}_{3}\right]$ molar ratio and reduce the $\mathrm{SS}$ from the activating solution.

The particle size distribution of the precursor materials was determined using a CILAS 1090 laser diffraction particle size analyser; the mean particle size was $0.37 \mu \mathrm{m}$ for SF and $2.12 \mu \mathrm{m}$ for MK. This difference in particle size may affect the workability of the produced mortars, i.e., possible reduction of the consistency with the increase of the SF content in the mortars. However, it should be noted that consistency was not fixed for mortars produced in this work; in contrary, the decision was to keep the $\mathrm{H}_{2} \mathrm{O} / \mathrm{Na}_{2} \mathrm{O}$ molar ratio constant with a value equal to 12.8 in order to ensure that the total amount of water was the same for all formulations. Therefore, the fineness of the particles is not the only parameter that can influence the workability of the studied mortars.

The alkaline activator is composed of sodium hydroxide $(\mathrm{NaOH})$ solution (50\% vol.), sodium silicate (SS) $\left(31.79 \% \mathrm{SiO}_{2}\right.$; $15.00 \% \mathrm{Na}_{2} \mathrm{O} ; 53.21 \% \mathrm{H}_{2} \mathrm{O}$ ) and extra water.

Fine sands are regarded as suitable aggregates for the development of high-performance cementitious composites ( $\mathrm{Li}$ et al., 2001). Therefore, fine quartz sand (passing $0.6 \mathrm{~mm}$, fineness modulus of 1.03) was used as aggregate.

The matrices were reinforced with REC15 PVA fibers supplied by Kuraray Co. Ltd; these fibers have a diameter of $40 \mu \mathrm{m}$, length of $8.0 \mathrm{~mm}$, tensile strength $=1,600 \mathrm{MPa}$ and an elongation of $6 \%$ and modulus of Young of $41 \mathrm{GPa}$.

\section{Methods}

Seven different mortar formulations were studied, three with a $\left[\mathrm{SiO}_{2}\right] /\left[\mathrm{Al}_{2} \mathrm{O}_{3}\right]$ molar ratio equal to 3.0 and four with this molar ratio equal to 3.8. The formulations, their mix design and the respective activation parameters are shown in Table $\mathbf{1 .}$
The formulation code describes the matrix $\left[\mathrm{SiO}_{2}\right] /\left[\mathrm{Al}_{2} \mathrm{O}_{3}\right]$ molar ratio (3.0 or 3.8), as well as the mass ratio between each precursor (MK and SF) used.

The amount of sodium hydroxide and sodium silicate used in each formulation varied to ensure that the total $\left[\mathrm{SiO}_{2}\right] /\left[\mathrm{Al}_{2} \mathrm{O}_{3}\right]$ molar ratio of each system is equal to 3.0 or 3.8 . $\left[\mathrm{Na}_{2} \mathrm{O}\right] /\left[\mathrm{SiO}_{2}\right]$ and $\left[\mathrm{H}_{2} \mathrm{O}\right] /\left[\mathrm{Na}_{2} \mathrm{O}\right]$ molar ratios were held constant for all formulations with values equal to 0.26 and 12.80 , respectively. By fixing these parameters, $\left[\mathrm{Na}_{2} \mathrm{O}\right] /\left[\mathrm{Al}_{2} \mathrm{O}_{3}\right]$ molar ratio has values of 0.78 or 0.99 for mortars with $\left[\mathrm{SiO}_{2}\right] /\left[\mathrm{Al}_{2} \mathrm{O}_{3}\right]$ ratio equal to 3.0 or 3.8 , respectively.

An aggregate to binder (MK and SF) mass ratio equal to 1 was used for all formulations. This value was determined in preliminary tests; molding fiber-reinforced AAM becomes impracticable when higher aggregate to binder ratios are used. All mortars were reinforced with $2 \%$ vol. content of fibers, as used in other studies (Li et al., 2001; Lee et al., 2012; Nematollahi et al., 2014; Borges et al., 2017).

The addition of PVA fibers significantly alters the workability of the mortars; therefore, the amount of water (which determines the $\left[\mathrm{H}_{2} \mathrm{O}\right] /\left[\mathrm{Na}_{2} \mathrm{O}\right]$ molar ratio) employed in each formulation was experimentally determined and later on fixed to enable the mixing and compaction of all mortars. In other words, although the solution to binder ratios varied between 0.91 and 1.23 for the composites (Table 1), this variation occurs due to the increase of soluble silica in the activator, rather than an increase in the amounts of $\mathrm{H}_{2} \mathrm{O}$ or $\mathrm{Na}_{2} \mathrm{O}$.

SF was supplied in powder; however, to ensure full dissolution, it was dissolved in the $\mathrm{NaOH}$ solution $24 \mathrm{~h}$ prior to mixing, as recommended by Bernal et al. (2012). In the following day, extra water and the SS solution were added to the activator (initially composed of $\mathrm{NaOH}+\mathrm{SF}$ ), resulting in the activating solution used in each formulation.

For each activating solution produced it is possible to calculate (i) the silica concentration provided by the SS as a function of the $\mathrm{Na}_{2} \mathrm{O}$ concentration and (ii) the total soluble silica concentration (provided by the SS and the dissolved SF) as a function of $\mathrm{Na}_{2} \mathrm{O}$ concentration. Those parameters are presented in the last two columns of Table 1. Table 1 shows that the overall $\left[\mathrm{SiO}_{2}\right] /\left[\mathrm{Na}_{2} \mathrm{O}\right]$ ratio in the activator is always equal to 1.29 or 1.83 for mortars with $\left[\mathrm{SiO}_{2}\right] /\left[\mathrm{Al}_{2} \mathrm{O}_{3}\right]$ ratio equal to 3.0 or 3.8 , respectively. However, the $\left[\mathrm{SiO}_{2}\right] \_\mathrm{SS} /\left[\mathrm{Na}_{2} \mathrm{O}\right]$ _sol. ratio gradually decreases from 1.40 to 0.88 as $\mathrm{SF}$ replaces $\mathrm{MK}$ in the mortars.

The mixing procedure started by mixing MK with the activating solution in a mortar mixer at low speed, until the paste was homogeneous. The aggregates were slowly added and the mixing continued at high speed until fully homogenization of the mortar. The mixer was set again to low speed while the PVA fibers were added. The composites were cast and cured at ambient temperature $\left(\sim 28^{\circ} \mathrm{C}\right)$. After $24 \mathrm{~h}$ they were demoulded and kept in plastic bags until the testing age (28 days), in order to avoid water loss and possible cracking.

\section{Mortar Characterization}

The consistency of the composites was determined by the flow table test, carried out according to the Brazilian standards NBR 
TABLE 1 | Mix design and activation parameters for the produced mortars.

\begin{tabular}{|c|c|c|c|c|c|c|c|}
\hline Formulation & $\begin{array}{l}{\left[\mathrm{SiO}_{2}\right] /} \\
{\left[\mathrm{Al}_{2} \mathrm{O}_{3}\right]}\end{array}$ & MK:SF (wt.) & $\begin{array}{l}\text { Solution to } \\
\text { binder (wt.) }\end{array}$ & $\begin{array}{l}\text { Sodium silicate/ } \\
\text { solution mass ratio }\end{array}$ & {$\left[\mathrm{SiO}_{2}\right]_{-\mathrm{ss}} /\left[\mathrm{Na}_{2} \mathrm{O}\right]_{- \text {sol. }}$} & $\begin{array}{l}{\left[\mathrm{SiO}_{2}\right] /\left[\mathrm{Na}_{2} \mathrm{O}\right] \text { in }} \\
\text { the activator }\end{array}$ & {$\left[\mathrm{H}_{2} \mathrm{O}\right]$} \\
\hline $3.0100 \mathrm{MK}-00 \mathrm{SF}$ & 3.00 & 100:00 & 1.05 & 0.66 & 1.29 & 1.29 & 18.12 \\
\hline 3.0 96MK-04SF & 3.00 & $96: 04$ & 0.97 & 0.56 & 1.06 & 1.29 & 17.41 \\
\hline 3.0 93MK-07SF & 3.00 & $93: 07$ & 0.91 & 0.48 & 0.88 & 1.29 & 16.87 \\
\hline 3.8 91MK-09SF & 3.80 & $91: 09$ & 1.23 & 0.70 & 1.40 & 1.83 & 20.92 \\
\hline $3.888 \mathrm{MK}-12 \mathrm{SF}$ & 3.80 & $88: 12$ & 1.16 & 0.64 & 1.24 & 1.83 & 20.25 \\
\hline 3.8 85MK-15SF & 3.80 & $85: 15$ & 1.09 & 0.57 & 1.07 & 1.83 & 19.57 \\
\hline 3.8 82MK-18SF & 3.80 & $82: 18$ & 1.02 & 0.48 & 0.89 & 1.83 & 18.90 \\
\hline
\end{tabular}

7215 (Associação Brasileira de Normas Técnicas, 1996) and NBR 13276 (Associação Brasileira De Normas Técnicas, 2016). This test was not carried out for unreinforced mortars, as they were extremely fluid.

Compressive strength and static modulus of elasticity tests were carried out at 28 days of ambient curing according to the standard NBR 7215 (Associação Brasileira de Normas Técnicas, 1996) and NBR 8522 (Associação Brasileira de Normas Técnicas, 2017) respectively; four cylindrical specimens $(50 \times 100) \mathrm{mm}$ of each formulation were tested using an EMIC DL 30000 universal equipment, with load cell with $300 \mathrm{KN}$ capacity. For the modulus of elasticity, the deformations of the specimens were measured by an electronic strain gauge with maximum measurable deformation of $2.5 \mathrm{~mm}$ and $0.0001 \mathrm{~mm}$ accuracy.

Three-point bending tests were performed as described in ASTM C 293 standard (American Society For Testing Materials, 2002). Four prismatic specimens $(160 \times 40 \times 40 \mathrm{~mm}$; spam $=$ $120 \mathrm{~mm}$ ) were tested for each mortar formulation, at a loading rate equal to $(1.0 \pm 0.1) \mathrm{MPa} / \mathrm{min}$. The electronic deflectometer used to measure the specimen's displacement during the test has $0.001 \mathrm{~mm}$ of resolution and maximum measurable deflection of $12.5 \mathrm{~mm}$. The first crack strength and peak strength (modulus of rupture-MOR) were determined.

The mortar's water absorption was determined by immersion in water under vacuum (RILEM, 1984) for four specimens of each of the formulations.

\section{Deformation Capability Parameters}

In a second stage of this work, it was decided to reduce the number of formulations to two matrices with different $\mathrm{SiO}_{2} / \mathrm{Al}_{2} \mathrm{O}_{3}$ ratios; the first with $\left[\mathrm{SiO}_{2}\right] /\left[\mathrm{Al}_{2} \mathrm{O}_{3}\right]$ ratio equal to 3.0 and neat $\mathrm{MK}(3.0100 \mathrm{MK}-00 \mathrm{SF})$ and the other one with $\left[\mathrm{SiO}_{2}\right] /\left[\mathrm{Al}_{2} \mathrm{O}_{3}\right]$ equal to 3.8 and maximum amount of SF (3.8 82MK-18SF). Those extremes in the formulation envelope represented the largest reduction in the amount of SS used in the matrix composition and, therefore, the biggest environmental appeal. Direct tensile test, single fiber pullout test and matrix fracture toughness test were carried out for these two mortars, in order to better understand the deformation capability of those materials.

The single fiber pullout test is a commonly used technique to investigate the interface properties between fiber and matrix, where physical and chemical interactions occur. Those interactions can be quantified from the load and displacement values obtained in the test, by means of properties like the adhesional stress $\left(\tau_{\mathrm{a}}\right)$, the frictional stress at the beginning of fiber $\operatorname{slip}\left(\tau_{\mathrm{b}}\right)$, the maximum shear stress $\left(\tau_{\max }\right)$ and chemical bond $\left(\mathrm{G}_{\mathrm{d}}\right)$ between fiber and matrix. The stress to which the fiber is subjected $(\tau)[\mathrm{MPa}]$ can be calculated from the Equation 2 (Redon et al., 2001):

$$
\tau=\frac{P}{\pi d_{f} L_{e}}
$$

where $\mathrm{P}$ is the applied load $[\mathrm{N}] ; \mathrm{d}_{\mathrm{f}}$ is the fiber diameter $[\mathrm{mm}]$ and $\mathrm{L}_{e}$ is the fiber embedment length $[\mathrm{mm}]$ in the matrix.

Equation 3 can be applied to estimate the superficial stress due to the chemical bonding $\left(\mathrm{G}_{\mathrm{d}}\right)[\mathrm{N} / \mathrm{mm}]$ between fiber and matrix, based on the maximum load $[\mathrm{N}]$ supported until the loss of bond $\left(\mathrm{P}_{\mathrm{a}}\right)$ and the initial friction loading $[\mathrm{N}]$ in the sliding step $\left(\mathrm{P}_{\mathrm{b}}\right)$ (Redon et al., 2001):

$$
G_{d}=\frac{2\left(P_{a}-P_{b}\right)^{2}}{\pi^{2} E_{f} d_{f}^{3}}
$$

where $E_{f}$ is the modulus of elasticity of the fiber $\left[\mathrm{N} / \mathrm{mm}^{2}\right]$.

The crack opening $\delta_{0}[\mathrm{~mm}]$ that corresponds to the maximum bond stress $\left(\sigma_{\mathrm{o}}\right)[\mathrm{MPa}]$ that prevents crack propagation, can be calculated with Equation 4 (Wang and Li, 2007):

$$
\delta_{0}=\frac{\tau_{0} L_{e}^{2}}{d_{f E_{f}}}-\frac{2 G_{d}}{\tau_{0}}
$$

Equation 5 gives the maximum bond strength corresponding to $\delta_{0}$ (Wang and Li, 2007):

$$
\sigma(\delta)=\left\{\begin{array}{l}
2 V_{f} \sqrt{\left(2 G_{d}+\tau_{0} \delta\right) \frac{E_{f}}{d_{f}}}-\frac{V_{f} E_{f} \delta}{L_{e}} \quad \delta \leq \delta_{c} \\
\frac{4 V_{f} \tau_{0}}{L_{e} d_{f}}\left(\frac{L_{e}}{2}-\delta\right)^{2} \quad \delta_{c}<\delta \leq \frac{L_{e}}{2}
\end{array}\right.
$$

where $\delta_{c}$ corresponds to the critical crack opening [mm] in which the fibers lose adhesion with the matrix and $V_{\mathrm{f}}$ is the volume of fibers [\%]. 
For the specimens casting, a single short PVA fiber was inserted into the end of a hollow cannula. Each of the fibers was attached to the cannula with wax in a way to ensure a $4 \mathrm{~mm}$ embedment length in the matrix. Figure 1 shows the mold used in the preparation of the specimens for the single fiber pullout test and the detail of fiber positioning in the cannula. The produced specimens have cylindrical geometry $(2.5 \mathrm{~cm}$ diameter $\times 2.5$ $\mathrm{cm}$ height).

The single fiber pullout tests were carried out in an MTS model 810 universal test equipment with $250 \mathrm{kN}$ load capacity and $100 \mathrm{~N}$ load transducer. The displacement rate employed was $0.02 \mathrm{~mm} / \mathrm{min}$. Six specimens from each formulation were tested at the age of 28 days. The displacement was measured by the actuator displacement. Figure 2 shows the assembly of the test and the detail shows how the fibers were fixed to a metal plate coupled to the load cell, using a universal instant adhesive.

The fracture toughness corresponds to the measure of the magnitude of the existing concentration of tension when a crack begins to propagate. Three-point bending tests on notched prismatic specimens are usually carried out to evaluate properties related to the matrix fracture, including modulus of elasticity $\left(\mathrm{E}_{\mathrm{m}}\right)\left[\mathrm{N} / \mathrm{m}^{2}\right]$, matrix fracture toughness $\left(\mathrm{K}_{\mathrm{m}}\right)$ $\left[\mathrm{N} \cdot \mathrm{m}^{3 / 2}\right]$, and effective critical depth of crack opening $\left(\mathrm{a}_{\mathrm{c}}\right)[\mathrm{m}]$. According to RILEM TC 89-FMT recommendation (RILEM, $1990)$, parameters related to matrix fracture can be calculated according to Equations 6-8:

$$
\begin{aligned}
E_{m} & =\frac{6 S a_{0} V_{1}(\alpha)}{C_{i} d^{2} b} \\
V_{1}(\alpha) & =0.76-2.28 \alpha+3.87 \alpha^{2}-2.04 \alpha^{3}+\frac{0.66}{(1-\alpha)^{2}} \\
\alpha & =\frac{a_{0}+H O}{d+H O}
\end{aligned}
$$

where $\mathrm{E}_{\mathrm{m}}$ is the material modulus of elasticity; $\mathrm{S}$ is the adopted spacing between supports $[\mathrm{m}] ; \mathrm{a}_{0}$ is the initial notch depth $[\mathrm{m}]$; $\mathrm{C}_{\mathrm{i}}$ is the initial compliance $\left[\mathrm{m} . \mathrm{N}^{-1}\right.$ ] calculated from the initial slope of the load $\times$ crack mouth opening displacement (CMOD) curve; $d$ is the specimen height $[\mathrm{m}]$; $b$ is the specimen width [m]; and $\mathrm{HO}$ is the thickness $[\mathrm{m}]$ of the metal sheet that supports the clip gauge.

From the modulus of elasticity $\left(\mathrm{E}_{\mathrm{m}}\right)$ calculated by the Equation 6, the effective critical crack depth $\left(a_{c}\right)$ can be obtained by means of an interactive process to satisfy Equation 9 (RILEM, 1990):

$$
E_{m}=\frac{6 S a_{c} V_{1}(\alpha)}{C_{u} d^{2} b}
$$

where $\mathrm{C}_{\mathrm{u}}$ is the compliance $\left[\mathrm{m} \cdot \mathrm{N}^{-1}\right]$ when a discharge corresponding to $95 \%$ of the maximum load is reached, calculated from the slope of the load $\times$ CMOD curve.

The matrix fracture toughness $\left(\mathrm{K}_{\mathrm{m}}\right)\left[\mathrm{N} . \mathrm{m}^{3 / 2}\right]$ can be calculated from Equations 10-13 (RILEM, 1990):

$$
\begin{aligned}
K_{m} & =3\left(P_{\text {max }}+0.5 W\right) \frac{S\left(\pi a_{c}\right)^{\frac{1}{2}} F(\alpha)}{2 d^{2} b} \\
F(\alpha) & =\frac{1.99-\alpha(1-\alpha)\left(2.15-3.93 \alpha+2.7 \alpha^{2}\right)}{\sqrt{\pi}(1+2 \alpha)(1-\alpha)^{\frac{3}{2}}} \\
\alpha & =\frac{a_{c}}{d} \\
W & =\frac{W_{0} S}{L}
\end{aligned}
$$

where $P_{\max }$ is the maximum load $[\mathrm{N}]$ measured in the test; $\mathrm{S}$ is the adopted spacing between supports $[\mathrm{m}] ; \mathrm{W}_{0}$ is the weight of the specimen $[\mathrm{N}]$; and $\mathrm{L}$ is the length of the specimen $[\mathrm{m}]$.

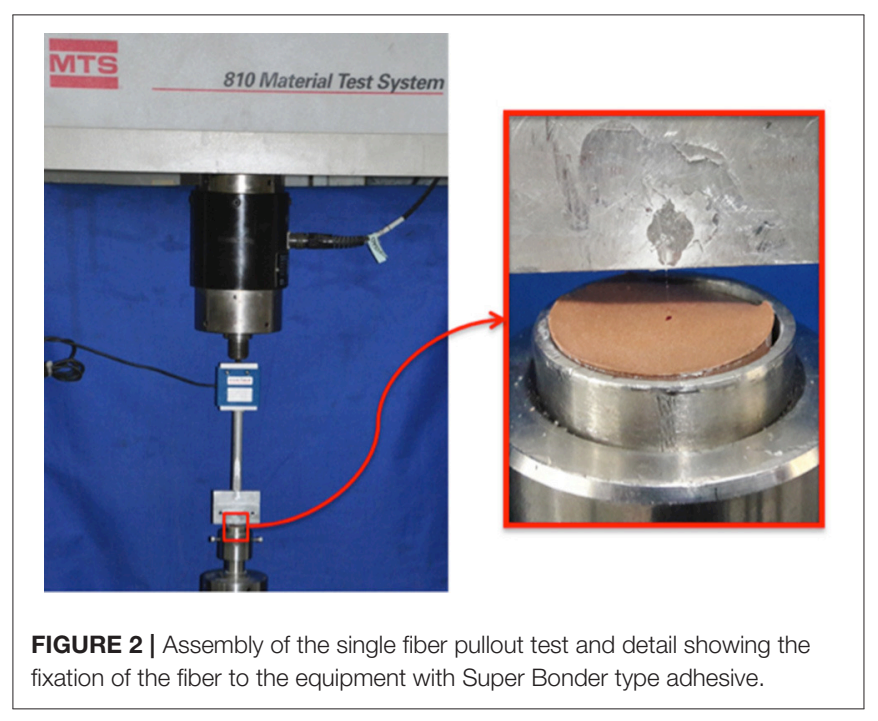

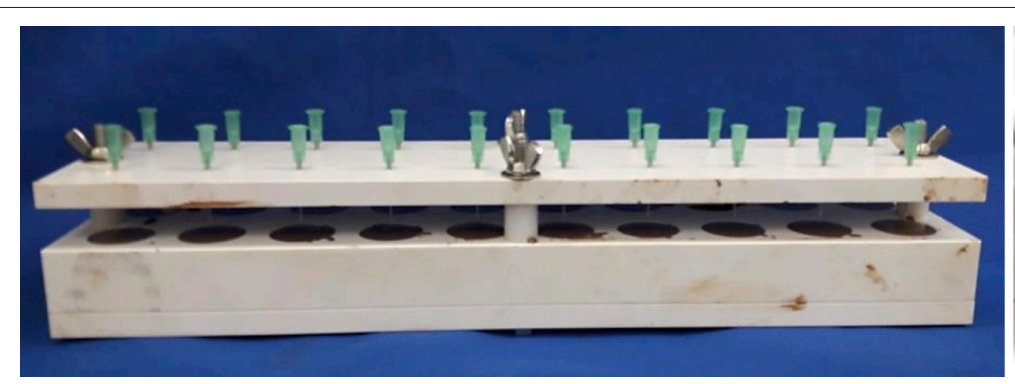

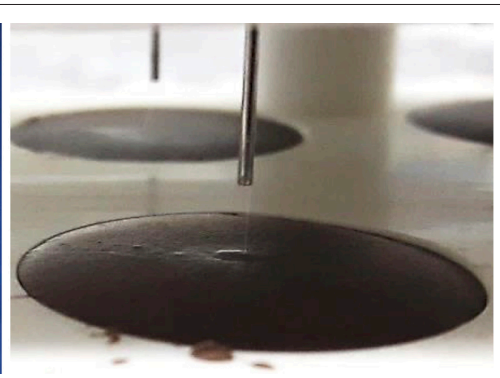

FIGURE 1 | Mold used to produce the specimens for the single fiber pullout test and detail of the fiber positioning in the cannula. 
Ten prismatic $(160 \times 40 \times 40) \mathrm{mm}$ specimens were tested for each of the two investigated formulations $(3.0100 \mathrm{MK}$ 00SF and 3.8 82MK-18SF), with a $1.5 \mathrm{~mm}$ thickness by $12 \mathrm{~mm}$ height notch.

The fracture toughness tests were performed in an MTS model 204.63 reaction frame with a servo-hydraulic actuator, with 100 $\mathrm{kN}$ load capacity. The distance between the supports was set at $120 \mathrm{~mm}$ and the loading rate used was equal to $0.008 \mathrm{~mm} / \mathrm{min}$. The crack mouth opening displacement (CMOD) was measured by a clip gauge attached to two metal plates and positioned in the center of the notch. The metallic plates were previously fixed to the specimens with adhesive plastic mass. The thickness (HO) of the metal plates is equal to $2 \mathrm{~mm}$.

The direct tensile test gives the fracture process of the studied composites, allowing the identification of strain-hardening or strain-softening behavior; it also provides one of the parameters required by the micromechanical model to describe the materials' behavior. The first crack stress and deformation values were determined, as well as the maximum strength and deformation capability presented by the material after the initial cracking. It is important to note the complexity of this test, considering that the sample misalignment in relation to the axis of load application can generate undesired torsion or bending stresses, which may lead to premature failure of the specimens. The tests were performed at the age of 28 days, using four dumbbell specimens ( $24 \mathrm{~mm} \times 40 \mathrm{~mm}$ central section and $250 \mathrm{~mm}$ length), as adopted by Mechtcherine et al. (2011), for each formulation. The tests were performed in an MTS model 810 universal test equipment with $250 \mathrm{kN}$ load capacity. The loading rate employed is equal to $0.06 \mathrm{~mm} / \mathrm{min}$ and the displacements were measured by two linear variable displacement transducers (LVDT), positioned on the specimen's sides, with a measurement length equal to $100 \mathrm{~mm}$. The assembling of the direct tensile test is shown in Figure 3.

With the capability parameters presented above, it was possible to use the two PSH indexes (Equations

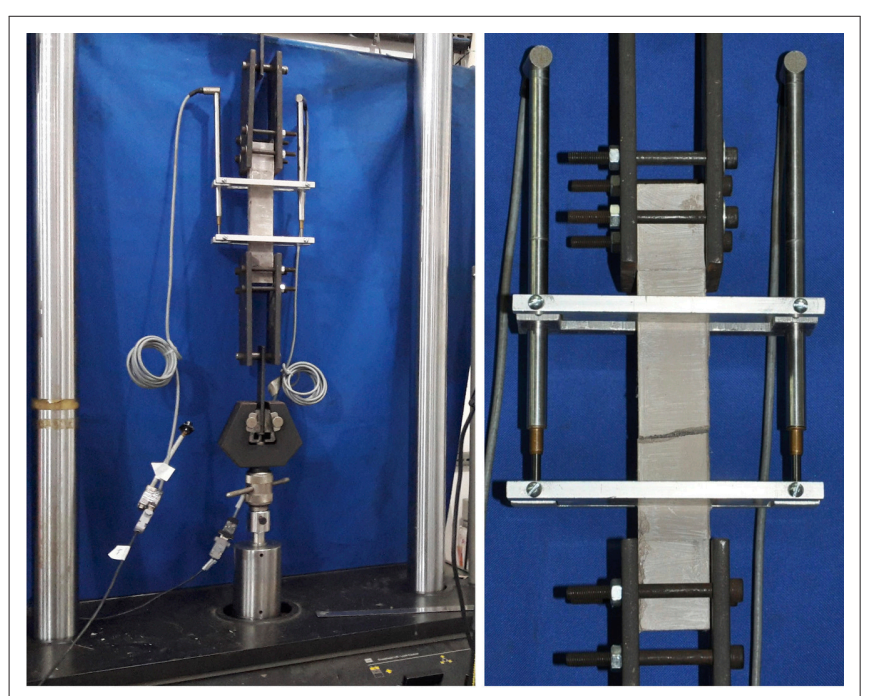

FIGURE 3 | Assembling the tensile strength test and fractured specimen.
$14,15)$ to evaluate the deformation performance of the composites (Kanda and Li, 2006):

$$
\begin{aligned}
P S H_{\text {energy }} & =\frac{J_{b}{ }^{\prime}}{J_{\text {tip }}} \\
P S H_{\text {tension }} & =\frac{\sigma_{0}}{\sigma_{c c}}
\end{aligned}
$$

\section{RESULTS AND DISCUSSION}

\section{Flow Table Test}

Figure 4 shows the flow table test results (spreading in $\mathrm{mm}$ ) for the fiber-reinforced mortars, as well as the solution/binder ratio adopted for each formulation and the SS/solution mass ratio (y-axis).

It can be noticed that the increase in the amount of SF in the formulations does not seem to negatively affect the workability of the AAM. SF particles are thinner than MK ones, but they are also spherical; therefore, their incorporation in AAM may lead to a lower solution demand to maintain the same workability, as already verified by Rodríguez et al. (2013).

Figure 4 shows a slight increase in the consistency (measured by the flow table test) of the mortars with $\left[\mathrm{SiO}_{2}\right] /\left[\mathrm{Al}_{2} \mathrm{O}_{3}\right]$ ratio equal to 3.8 when compared to those with this ratio equal to 3.0. This behavior is probably related to the solution/binder ratio employed (black dotted curve in Figure 4): 0.92-1.92 for mortars with $\left[\mathrm{SiO}_{2}\right] /\left[\mathrm{Al}_{2} \mathrm{O}_{3}\right]=3.0$ against $0.94-2.37$ for those with $\left[\mathrm{SiO}_{2}\right] /\left[\mathrm{Al}_{2} \mathrm{O}_{3}\right]=3.8$. However, this relationship is not linear. For example, the formulation $3.0100 \mathrm{MK}-$ 00SF has solution/binder ratio equal to 1.05 and a flow table $=190 \mathrm{~mm}$; the formulation $3.882 \mathrm{MK}-18 \mathrm{SF}$ has lower solution/binder ratio (1.02) and higher flow table $(235 \mathrm{~mm})$. The same trend is found for the SS/solution ratio (gray dotted curve in Figure 4). Therefore, in general the variation of the solution/solids ratio or the SS/solution mass ratio did not influence the mortar's consistency for both series with the same $\left[\mathrm{SiO}_{2}\right] /\left[\mathrm{Al}_{2} \mathrm{O}_{3}\right]$ ratio.

\section{Compressive Strength and Modulus of Elasticity}

Figure 5 shows the results of compressive strength, corresponding to the average of four specimens for each mortar. It is possible to see that the compressive strength significantly vary neither with the change in the $\left[\mathrm{SiO}_{2}\right] /\left[\mathrm{Al}_{2} \mathrm{O}_{3}\right]$ molar ratio nor with the increase of the SF percentage in the system (i.e., with a reduction in the $\left[\mathrm{SiO}_{2}\right]_{-} \mathrm{sS} /\left[\mathrm{Na}_{2} \mathrm{O}\right]$ _sol. ratio in the activating solutions). These results indicate that the SF is effectively reacting and may reduce the demand for SS in AAM without any significant impact on the compressive strength of these composites.

It could be expected that fiber-reinforced composites would have slightly lower compressive strength than non-reinforced composites. The fiber addition usually reduces the compressive strength of cementitious composites, as a consequence of the interface between fiber and matrix, with possible sites for the formation and propagation of cracks and material failure at lower loadings (Bentur and Mindess, 2007). However, in general, there 


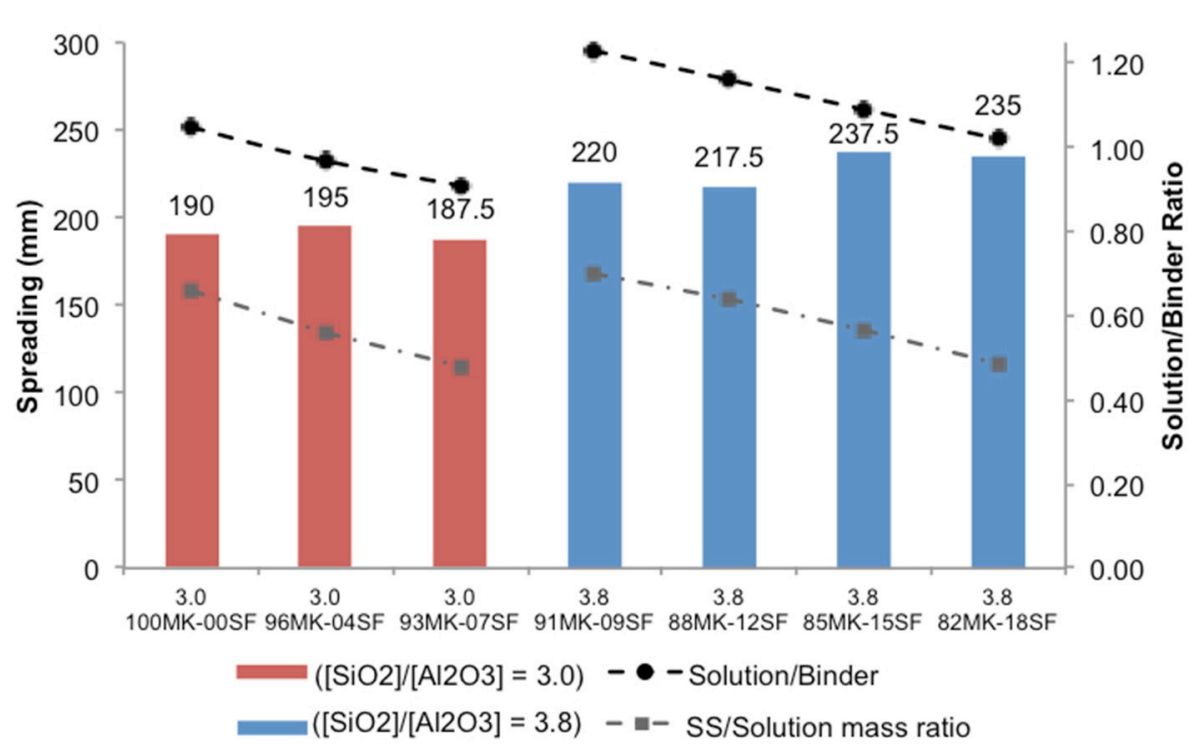

FIGURE 4 | Flow table test results for the fiber-reinforced mortars.

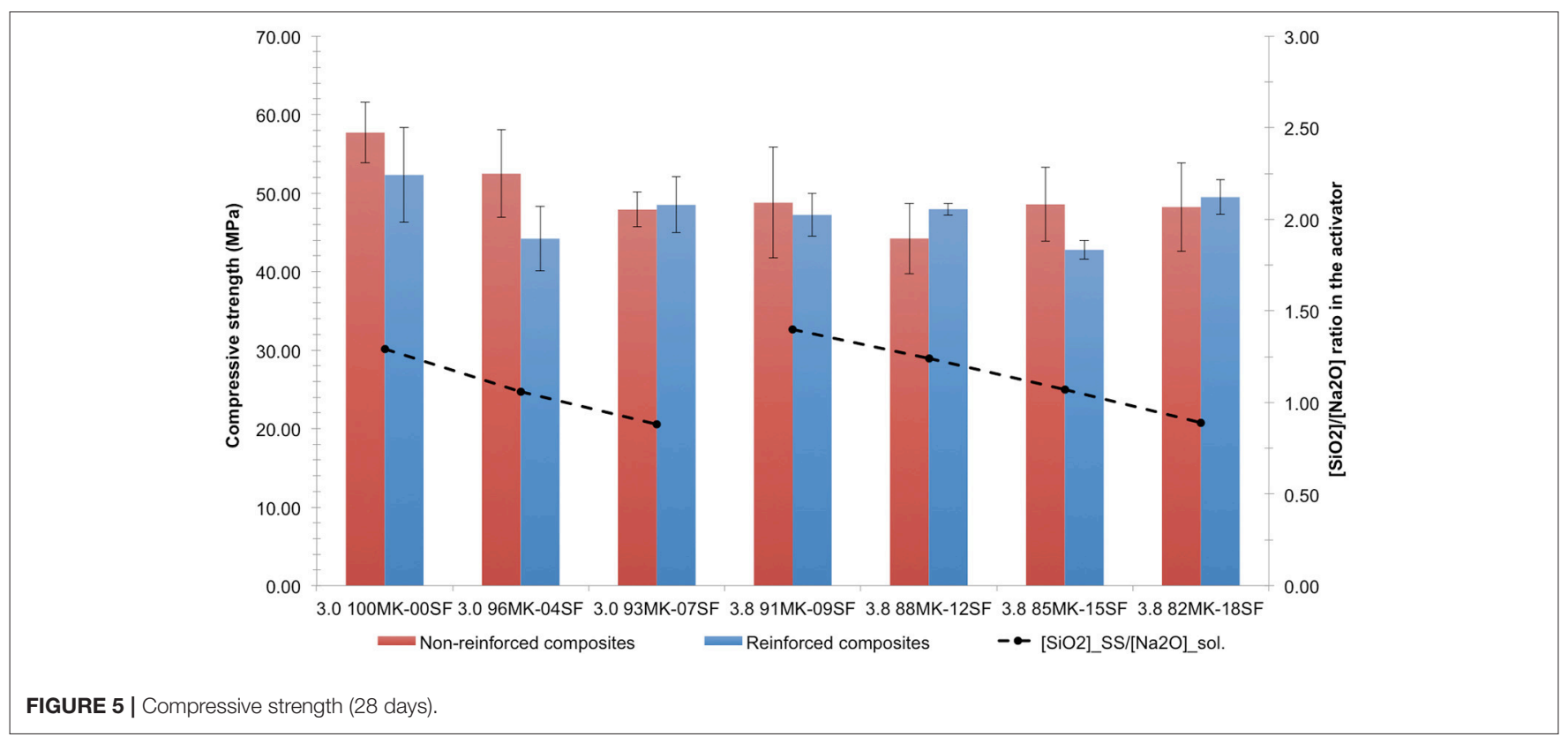

are no statistical variations in strength (marked by the error bars) for plain and reinforced composites. Therefore, for the MKbased AAM studied, the compressive strength is not significantly affected by the fiber addition.

It should be noted that the high standard deviations in the compressive strength for almost all formulations seem to be inherent to AAM, as previously reported in the literature (Provis et al., 2009). In addition, Bernal et al. (2012) reported that the replacement of SS with SF-based activators in the preparation of AAM seems to lead to higher variability in compressive strength results.
The results of the modulus of elasticity are shown in Figure 6. The presented values correspond to the average of four specimens for each formulation. In general, reference formulations (without fibers, red bars) have higher modulus of elasticity than those reinforced with fibers, but the difference is not significant. This behavior agrees with the results reported by Puertas et al. (2003) for the incorporation of polypropylene fibers in alkali-activated mortars, which led to a slight reduction in the modulus of elasticity in comparison to non-reinforced composites.

Figure 6 also shows an overall reduction in the modulus of elasticity for AAM with $\mathrm{SiO}_{2} / \mathrm{Al}_{2} \mathrm{O}_{3}=3.8$; within each of these 


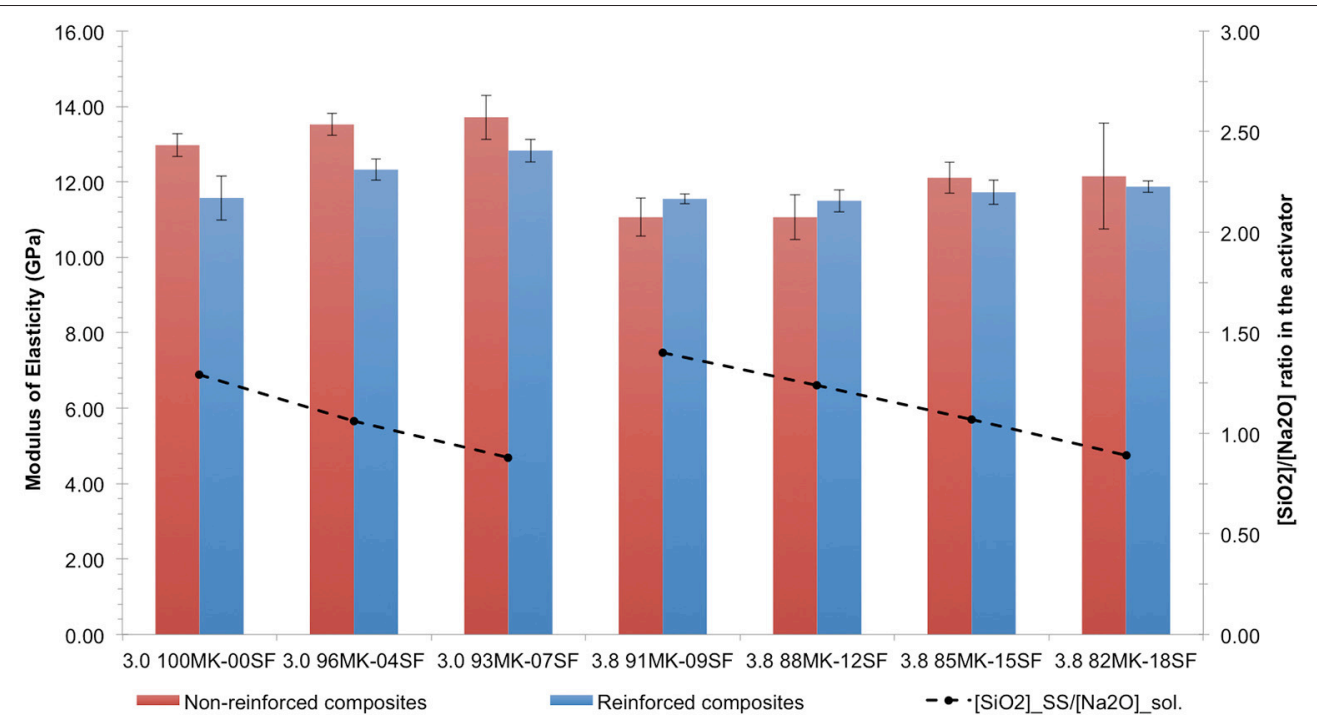

FIGURE 6 | Modulus of elasticity results.

series (3.0 or 3.8) the mean value of the modulus of elasticity appears to increase for higher amounts of SF.

Obonyo et al. (2011) stated that the modulus of elasticity is in the range of 4-35 GPa for geopolymers and other AAM. Němeček et al. (2011) argue that AAM have an inherent modulus of elasticity in a range between 17 and $18 \mathrm{GPa}$ and that this property appears to be, for a given formulation, independent of the precursor material or the type of curing regime employed. Ye et al. (2017) produced blast furnace slag based AAM with modulus of elasticity varying between 13.25 and $20.71 \mathrm{GPa}$.

Therefore, the modulus of elasticity of the studied composites seems to be slightly lower than those reported in the literature for AAM. However, as stated by Provis et al. (2014), research is still needed to establish the interrelationships between the binder structure and its elastic properties.

In addition, Bondar et al. (2010) argued that the development of the modulus of elasticity is directly related to the curing temperature; its increase is limited by the water/fine materials ratio, i.e., by the amount of water available to evaporate during the activation process (Bondar et al., 2010). The curing regime used in this paper (ambient temperature) is probably responsible for slightly lower results for the modulus of elasticity.

No clear relationship between the modulus of elasticity and the compressive strength was found for the studied AAM. This behavior is corroborated by the literature, which states that the modulus of elasticity of alkali-activated binders presents little variation with the increase in compressive strength (PachecoTorgal et al., 2009).

\section{Flexural Strength and Toughness}

Figures 7A,B shows the Load $(\mathrm{N}) \times$ Deflection $(\mathrm{mm})$ curves, for the series produced with $\left[\mathrm{SiO}_{2}\right] /\left[\mathrm{Al}_{2} \mathrm{O}_{3}\right]$ ratio equal to 3.0 and 3.8 , respectively, obtained for four specimens of each composite, as well as the distribution of the cracks in one of the specimens after the three-point bending tests. It is possible to notice that all the composites present deflection-hardening behavior, with increased strength capacity after the first crack. After the initial matrix cracking, mortars with $\left[\mathrm{SiO}_{2}\right] /\left[\mathrm{Al}_{2} \mathrm{O}_{3}\right]$ molar ratio equal to 3.0 had an average increase of $44 \%$ in flexural strength, against $47 \%$ in mortars with $\left[\mathrm{SiO}_{2}\right] /\left[\mathrm{Al}_{2} \mathrm{O}_{3}\right]$ molar ratio equal to 3.8 . It is worth to note that until the first crack, the fibers basically do not work, i.e., the load is supported mainly by the matrix until cracking (Bentur and Mindess, 2007).

The data provided by the Load $(\mathrm{N}) \times$ Deflection $(\mathrm{mm})$ curves (Figure 7) shows that there is a subtle reduction of flexural strength with the increase of $\left[\mathrm{SiO}_{2}\right] /\left[\mathrm{Al}_{2} \mathrm{O}_{3}\right]$ molar ratio from 3.0 to 3.8 , although these parameters may be considered the same when the standard deviation is taken into account. However, toughness of the reinforced mortars with $\left[\mathrm{SiO}_{2}\right] /\left[\mathrm{Al}_{2} \mathrm{O}_{3}\right]$ molar ratio equal to 3.8 is higher than that of the materials with this ratio equal to 3.0, which had already been described by Borges et al. (2017).

Figure 8 shows the toughness in flexion of the composites as a function of the amount of SF employed, $\left[\mathrm{SiO}_{2}\right]_{-} \mathrm{SS} /\left[\mathrm{Na}_{2} \mathrm{O}\right]_{-}$sol. and solution/binder ratio. At first, Figure 8A appears to indicate that the toughness of the composites increases with the SF addition. However, one may note that the toughness is roughly the same for composites with up to 7\% SF. Similarly, the toughness does not vary when SF content changes from 9 to $18 \%$. Figure 8B shows that the $\left[\mathrm{SiO}_{2}\right]_{-} s \mathrm{~s} /\left[\mathrm{Na}_{2} \mathrm{O}\right]_{-}$sol. molar ratio also does not play an important role in the toughness, which is roughly the same when the first is reduced from 1.40 to 0.89 for formulations with $\left[\mathrm{SiO}_{2}\right] /\left[\mathrm{Al}_{2} \mathrm{O}_{3}\right]=3.8$ or from 1.29 to 0.88 for formulations with $\left[\mathrm{SiO}_{2}\right] /\left[\mathrm{Al}_{2} \mathrm{O}_{3}\right]=3.0$. In that sense, SS may be successfully removed from the mixes without jeopardizing the toughness of MK-based alkali-activated composites. The solution/solids ratio did not determine the toughness behavior either. Figure 8C shows that the formulation 3.8 82MK-18SF 

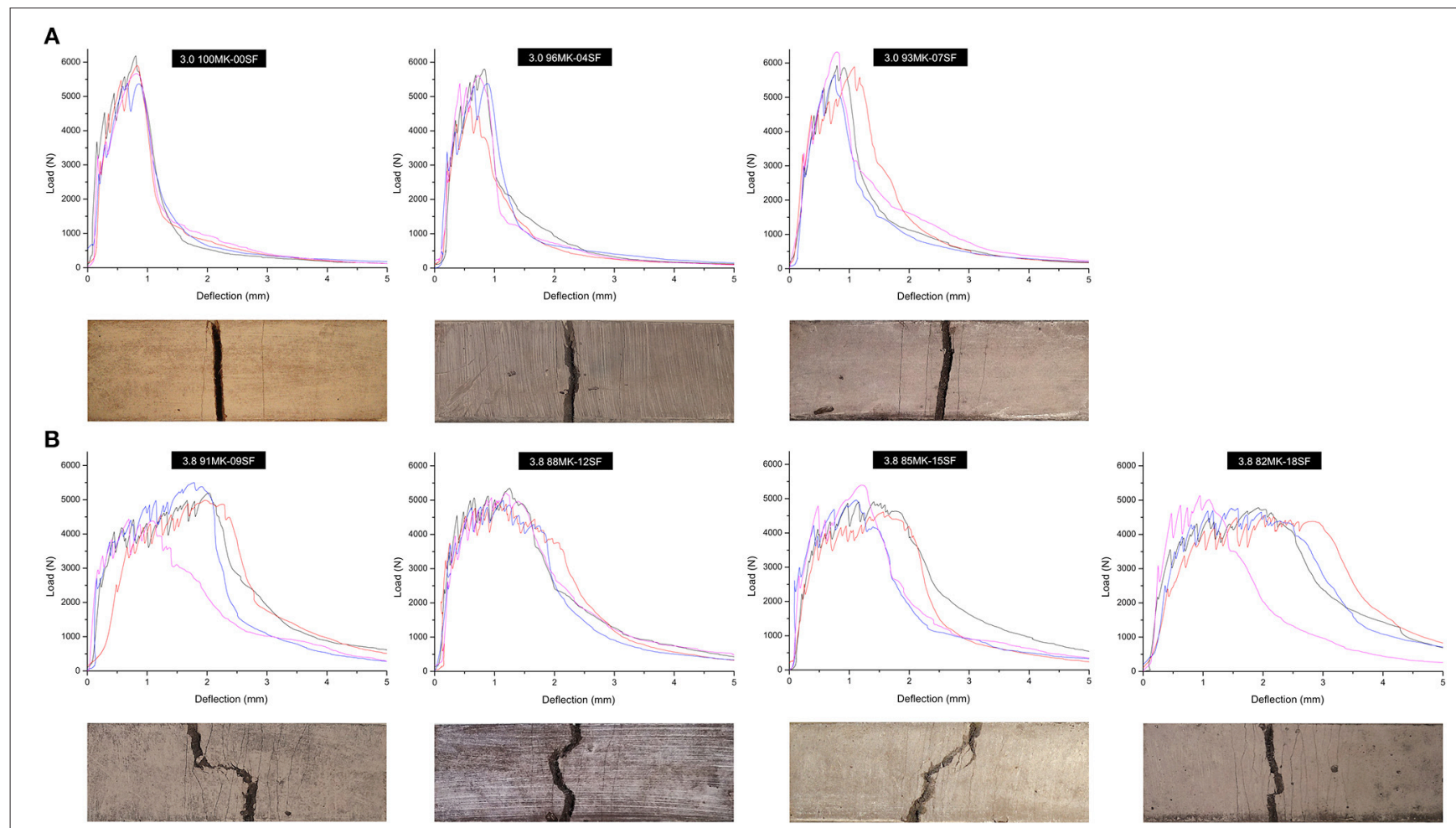

FIGURE 7 | Load $(\mathrm{N}) \times$ Deflection $(\mathrm{mm})$ curves and cracked specimens of mortars with $\left[\mathrm{SiO}_{2}\right] /\left[\mathrm{Al}_{2} \mathrm{O}_{3}\right]$ ratio equal to (A) 3.0 and (B) 3.8 .

with solution/binder ratio of 1.02 has double the toughness of 3.0 100MK-00SF, the latter with solution/binder of 1.05 .

In all three Figures $\mathbf{8 A - C}$ the toughness is affected by the $\left[\mathrm{SiO}_{2}\right] /\left[\mathrm{Al}_{2} \mathrm{O}_{3}\right]$ ratio, i.e., formulations with $\left[\mathrm{SiO}_{2}\right] /\left[\mathrm{Al}_{2} \mathrm{O}_{3}\right]=$ 3.8 have higher toughness than those with $\left[\mathrm{SiO}_{2}\right] /\left[\mathrm{Al}_{2} \mathrm{O}_{3}\right]=$ 3.0, as already seen in Table 5. Nevertheless, higher toughness in Figure 8 (6.37-8.38 J) corresponds to formulations with the overall $\left[\mathrm{SiO}_{2}\right] /\left[\mathrm{Na}_{2} \mathrm{O}\right]$ ratio in the activator equal to 1.83 , whereas the lower values of toughness (2.69-3.41) are found for those composites with this ratio equal to 1.29 , irrespective of changes in other activating parameters. In other words, the toughness of alkali-activated composites remains unaffected even when other significant changes in their composition take place, such as (i) the replacement of MK with SF; (ii) reduction of SS; and (iii) variation of solution/binder ratio.

\section{Apparent Dry Density, Porosity, and Water Absorption}

Apparent dry density $\left(\mathrm{g} / \mathrm{cm}^{3}\right)$, water absorption (\%), and apparent porosity (\%) values were calculated from data of the water absorption test; the mean value and the standard deviation (in parentheses) are presented in Table 2.

There was no significant variation of the apparent dry density, water absorption or apparent porosity between all the formulations, or between fiber-reinforced composites and those without reinforcement. This indicates that the reduction of SS in the activator (by replacing MK with SF) will not jeopardize the durability of the composites, as long as the $\left[\mathrm{H}_{2} \mathrm{O}\right] /\left[\mathrm{Na}_{2} \mathrm{O}\right]$ molar ration is kept constant.
It is important to remember that apparent dry density is also a function of the specific gravity of the precursors. The specific gravity is $2.22 \mathrm{~g} / \mathrm{cm}^{3}$ for SF and $2.56 \mathrm{~g} / \mathrm{cm}^{3}$ for MK. Thus, it makes sense that the apparent dry density of the produced composites decreases with the increase of the SF content, and consequently, with the reduction of $\mathrm{MK}$ amount in the composites. However, this is not a linear correlation, since other parameters change for different formulations, e.g., solution/solids ratio and $\mathrm{SS} / \mathrm{NaOH}$ mass ratio. Thus, the employment of SF in MK-based AAM could also contribute in the design of lighter structures, when compared to neat MK AAM.

\section{Single Fiber Pullout Test}

Figure 9 shows the pullout force $(\mathrm{N}) \times$ slipping $(\mathrm{mm})$ curves obtained in the PVA fiber pullout test, with $4 \mathrm{~mm}$ embedment length in the matrices $3.0100 \mathrm{MK}-00 \mathrm{SF}$ and 3.8 82MK-18SF. Six specimens were tested for each of the matrices.

There is a large variation in the results of the pullout test for different samples of the same matrix; however, in general a slightly greater slip of the fibers is observed in the matrix 3.0 $100 \mathrm{MK}-00 \mathrm{SF}$, when compared to the matrix 3.8 82-MK-18SF. Nevertheless, the pullout forces observed for the two matrices have similar values, way below the fibers tensile strength $(1,600$ $\mathrm{MPa}$, which corresponds to a $2 \mathrm{~N}$ loading).

Table 3 summarizes the main parameters related to the fibermatrix interface, calculated from the average of six tests, with standard deviation presented in parentheses.

It can be noticed that the design parameters related to the fiber-matrix interface can be considered essentially the same for 


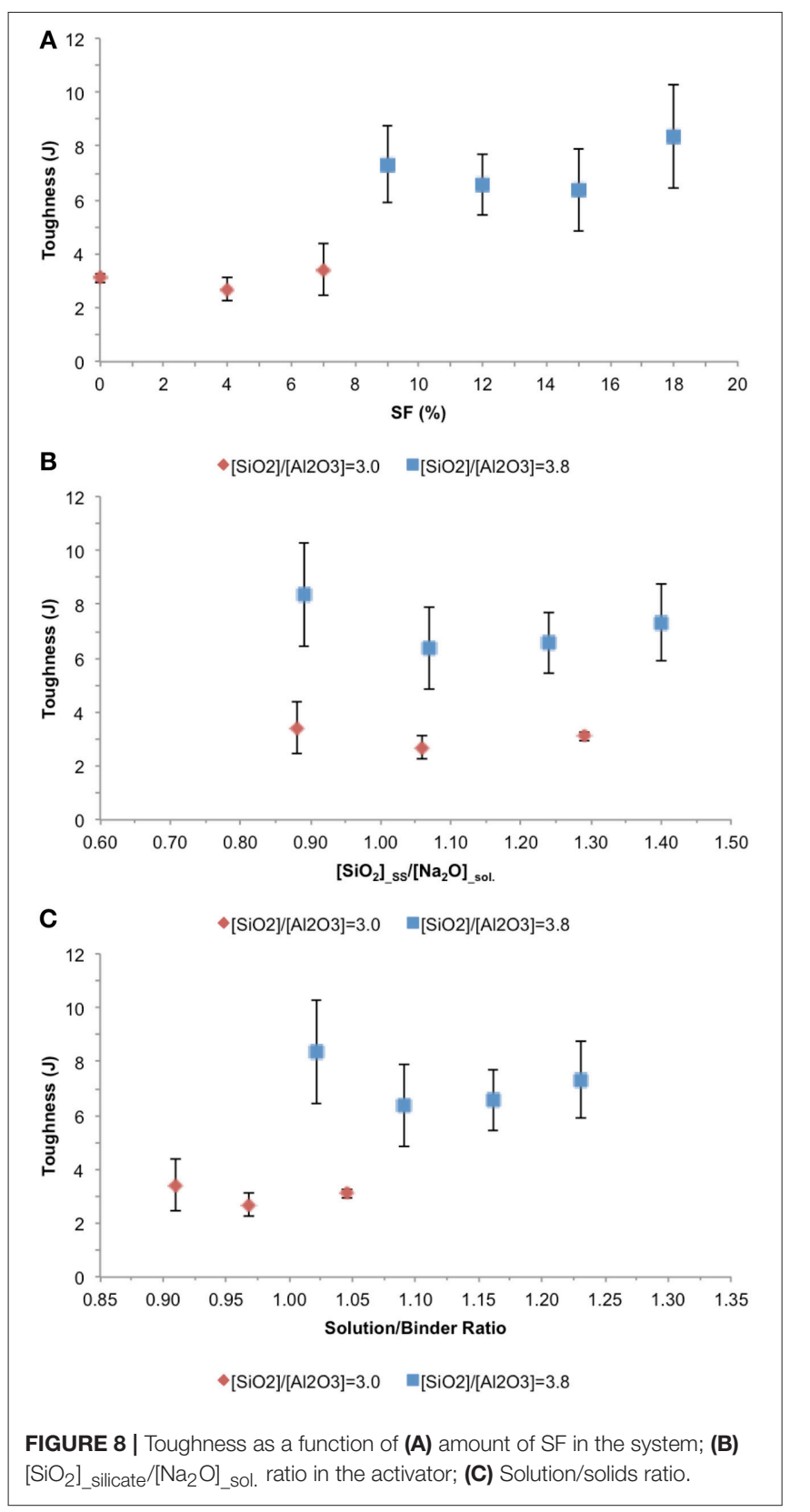

the two studied formulations. This behavior indicates once again that the SF incorporated into the matrix is effectively reacting and that the interface properties are not affected by the reduction of SS in the matrices. Comparing the mean values obtained for the two different formulations, results indicate that the chemical bond between fiber and matrix $\left(G_{d}\right)$, the required tension for adhesion loss $\left(\sigma_{\mathrm{a}}\right)$ and the frictional tension at the beginning of pullout $\left(\tau_{0}\right)$ are not significantly affected by the increase of the $\mathrm{SiO}_{2} / \mathrm{Al}_{2} \mathrm{O}_{3}$ ratio.

The comparison of these values with results described in the literature (Li et al., 2002; Oliveira, 2015; Nematollahi et al., 2017) indicates that the adhesion of PVA fibers to metakaolin-based alkali-activated matrixes is lower than that observed for fly ashbased AAM or for Portland cement matrices, behavior that may
TABLE 2 | Mortars apparent specific dry density, water absorption, and apparent porosity.

\begin{tabular}{|c|c|c|c|c|}
\hline \multicolumn{2}{|c|}{ Formulation } & \multirow{2}{*}{$\begin{array}{c}\begin{array}{c}\text { Apparent } \\
\text { dry density } \\
\left(\mathbf{g} / \mathbf{c m}^{3} \mathbf{)}\right.\end{array} \\
1.687(0.004)\end{array}$} & \multirow{2}{*}{$\begin{array}{c}\begin{array}{c}\text { Water } \\
\text { absorption } \\
\text { (\%) }\end{array} \\
16.61(0.05)\end{array}$} & \multirow{2}{*}{$\begin{array}{c}\begin{array}{c}\text { Apparent } \\
\text { porosity } \\
(\%)\end{array} \\
28.02(0.13)\end{array}$} \\
\hline $\begin{array}{l}\text { Non- } \\
\text { reinforced }\end{array}$ & $\begin{array}{l}3.0 \\
100 \mathrm{MK}-00 \mathrm{SF}\end{array}$ & & & \\
\hline composites & $\begin{array}{l}3.0 \\
96 \mathrm{MK}-04 \mathrm{SF}\end{array}$ & $1.673(0.005)$ & $16.97(0.07)$ & $28.40(0.12)$ \\
\hline & $\begin{array}{l}3.0 \\
93 \mathrm{MK}-07 \mathrm{SF}\end{array}$ & $1.668(0.007)$ & $17.26(0.03)$ & $28.80(0.13)$ \\
\hline & $\begin{array}{l}3.8 \\
91 \mathrm{MK}-09 \mathrm{SF}\end{array}$ & $1.634(0.005)$ & $17.95(0.14)$ & $29.33(0.27)$ \\
\hline & $\begin{array}{l}3.8 \\
88 \mathrm{MK}-12 \mathrm{SF}\end{array}$ & $1.627(0.005)$ & $18.40(0.16)$ & $29.95(0.23)$ \\
\hline & $\begin{array}{l}3.8 \\
85 \mathrm{MK}-15 \mathrm{SF}\end{array}$ & $1.621(0.005)$ & $18.58(0.08)$ & $30.12(0.10)$ \\
\hline & $\begin{array}{l}3.8 \\
82 \mathrm{MK}-18 \mathrm{SF}\end{array}$ & $1.612(0.012)$ & $18.81(0.07)$ & $30.33(0.26)$ \\
\hline \multirow[t]{7}{*}{$\begin{array}{l}\text { Reinforced } \\
\text { composites }\end{array}$} & $\begin{array}{l}3.0 \\
100 \mathrm{MK}-00 \mathrm{SF}\end{array}$ & $1.678(0.004)$ & $16.36(0.08)$ & $27.46(0.12)$ \\
\hline & $\begin{array}{l}3.0 \\
96 \mathrm{MK}-04 \mathrm{SF}\end{array}$ & $1.662(0.007)$ & $16.68(0.14)$ & $27.72(0.24)$ \\
\hline & $\begin{array}{l}3.0 \\
93 \mathrm{MK}-07 \mathrm{SF}\end{array}$ & $1.685(0.007)$ & $17.18(0.40)$ & $28.96(0.57)$ \\
\hline & $\begin{array}{l}3.8 \\
\text { 91MK-09SF }\end{array}$ & $1.647(0.010)$ & $17.34(0.28)$ & $28.57(0.39)$ \\
\hline & $\begin{array}{l}3.8 \\
88 \mathrm{MK}-12 \mathrm{SF}\end{array}$ & $1.641(0.011)$ & $17.56(0.26)$ & $28.80(0.35)$ \\
\hline & $\begin{array}{l}3.8 \\
85 \mathrm{MK}-15 \mathrm{SF}\end{array}$ & $1.609(0.006)$ & $18.47(0.32)$ & $29.72(0.54)$ \\
\hline & $\begin{array}{l}3.8 \\
82 \mathrm{MK}-18 \mathrm{SF}\end{array}$ & $1.612(0.007)$ & $18.38(0.14)$ & $29.63(0.15)$ \\
\hline
\end{tabular}

be related to both fiber embedment length in the matrix and to chemical properties of the matrices. The chemical bonding energy $\left(G_{d}\right)$ and the frictional tension at the beginning of the pullout $\left(\tau_{0}\right)$ have significantly lower values for the metakaolinbased AAM studied in this paper than those described in the literature. Therefore, it can be inferred that the fibers properties are not exploited to their full potential in this case, since sliding of fibers occurs without considerable resistance at the interface.

\section{Matrix Fracture Toughness}

Table 4 shows the parameters found in the fracture toughness test for the mortars $3.0100 \mathrm{MK}-00 \mathrm{SF}$ and 3.8 82MK-18SF. The mean values, obtained for 10 specimens of each formulation, are followed by the standard deviation in parentheses.

The modulus of elasticity $\left(\mathrm{E}_{\mathrm{m}}\right)$ found for the two composites agree with the values described in the literature. In addition, the matrices of both formulations present higher values of fracture toughness $\left(\mathrm{K}_{\mathrm{m}}\right)$ than those reported in the literature (Nematollahi et al., 2015). These high $\mathrm{K}_{\mathrm{m}}$ values result in high matrix crack tip toughness $\left(\mathrm{J}_{\text {tip }}\right)$, which may negatively influence the deformation capability of the composites when subjected to direct tensile stresses. 

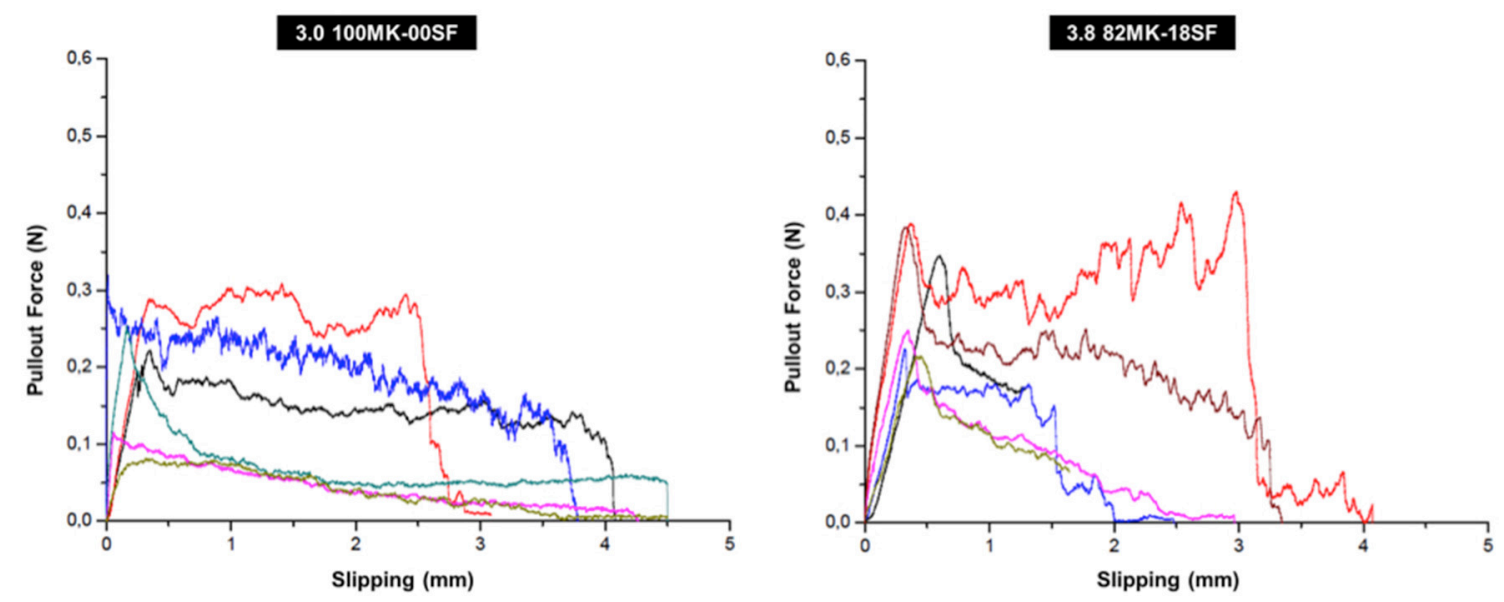

FIGURE 9 | Pullout curves for PVA fibers embedded $(\mathrm{Le}=4 \mathrm{~mm})$ in two alkali-activated matrices with different $\mathrm{SiO}_{2} / \mathrm{Al}_{2} \mathrm{O}_{3}$ ratios.

TABLE 3 | Main parameters obtained in the single fiber pullout test for two alkali-activated matrices with different $\mathrm{SiO}_{2} / \mathrm{Al}_{2} \mathrm{O}_{3}$ ratios.

\begin{tabular}{|c|c|c|c|c|c|c|c|}
\hline Formulation & $\mathrm{Pa}_{\mathrm{a}}(\mathrm{N})$ & $P_{b}(N)$ & $P_{\text {máx }}(\mathbf{N})$ & $\sigma_{a}(\mathrm{MPa})$ & $\sigma_{\mathrm{b}}$ or $\tau_{0}(\mathrm{MPa})$ & $\sigma_{\text {máx }}(\mathrm{MPa})$ & $G_{d}\left(J / m^{2}\right)$ \\
\hline 3.8 82MK-18SF & $0.30(0.08)$ & $0.24(0.09)$ & $0.31(0.09)$ & $0.60(0.16)$ & $0.48(0.19)$ & $0.61(0.18)$ & $0.34(0.28)$ \\
\hline
\end{tabular}

TABLE 4 | Matrix fracture toughness related properties.

\begin{tabular}{lcccc}
\hline Formulation & $\mathbf{P}_{\text {máx }}(\mathbf{N})$ & $\mathbf{E}_{\mathbf{m}}(\mathbf{G P a})$ & $\mathbf{K}_{\mathbf{m}}(\mathbf{M P a} \cdot \sqrt{\mathbf{m})}$ & $\mathbf{J}_{\text {tip }}\left(\mathbf{J} / \mathbf{m}^{\mathbf{2}}\right)$ \\
\hline 3.0 100MK-00SF & $709.51(28.17)$ & $12.34(0.87)$ & $0.62(0.02)$ & $31.04(2.38)$ \\
3.8 82MK-18SF & $663.86(64.33)$ & $9.22(1.65)$ & $0.54(0.07)$ & $31.73(3.94)$ \\
\hline
\end{tabular}

\section{Behavior in Direct Tensile Test}

Figure 10 shows the stress $(\mathrm{MPa}) \times$ strain $(\%)$ curves corresponding to the tensile tests performed for the two matrices. These results correspond to the mean value obtained for four specimens, with standard deviation presented in parentheses. The measured values of deformation correspond to the average of the readings of the two LVDT.

These curves show that both composites present a slight increase in strength after the initial cracking of the matrix; the formation of multiple cracks, however, occurs in reduced quantity. It is also noticeable that the first peak strength is quite high and very close to the maximum composite strength, characterizing the strain-softening behavior in tension, with little deformation until failure.

Like the flexural strength test (section Flexural Strength and Toughness), an increasing number of cracks is associated with a higher $\left[\mathrm{SiO}_{2}\right] /\left[\mathrm{Al}_{2} \mathrm{O}_{3}\right]$, i.e., equal to 3.8. However, this behavior is less pronounced in the direct tension test.

The analysis of the results indicates that the first crack strength of the matrices should be reduced in order to increase the deformation capability of the composites. In fact, very high $\sigma_{\mathrm{cc}}$ values (3.78 MPa for 3.0 100MK-00SF and 4.22 MPa for 3.8 $82 \mathrm{MK}-18 \mathrm{SF}$ ) lead to a reduction in the tension performance index $\left(\mathrm{PSH}_{\text {tension }}=\sigma_{0} / \sigma_{\mathrm{cc}}\right)$. This will be further discussed in section $\mathrm{PSH}_{\text {tension }}$ and $\mathrm{PSH}_{\text {energy }}$.

It was observed the formation of about 2 to 5 cracks and deformation capability of $0.20-0.30 \%$ for the studied composites. The literature (Ohno and Li, 2014; Nematollahi et al., 2017) describes AAM with similar fracture toughness $\left(K_{m}\right)$ and modulus of elasticity $\left(\mathrm{E}_{\mathrm{m}}\right)$ but with deformation capability of around $4 \%$ and with the development of an elevated number of cracks in the axial tensile test, although the maximum tensile strengths described are similar to the formulations produced in this study. Nevertheless, the comparison of the obtained results with the data found in the literature (Li et al., 2002; Ohno and Li, 2014; Nematollahi et al., 2015) demonstrates the feasibility of optimizing the matrix and interface properties to obtain high ductility AAM reinforced with PVA fibers. This is discussed in the following section.

\section{$\mathrm{PSH}_{\text {tension }}$ and $\mathrm{PSH}_{\text {energy }}$}

Parameters related to the micromechanical modeling criteria were calculated for the studied composites with the aim of describing their deformation capability (Table 5). Both $\mathrm{PSH}_{\text {tension }}$ and $\mathrm{PSH}_{\text {energy }}$ indexes have values lower than 1 for both composites. Therefore, the studied composites do not fit any of the two design criteria established for SHCC, considering those indexes. As previously discussed, they do not present the strainhardening behavior, despite the formation of multiple cracks.

The comparison between the obtained values and results described in the literature may indicate which parameters should be optimized for the production of strain-hardening AAM. According to Nematollahi et al. (2017), in order to obtain AAM with strain-hardening behavior and saturation in the number 

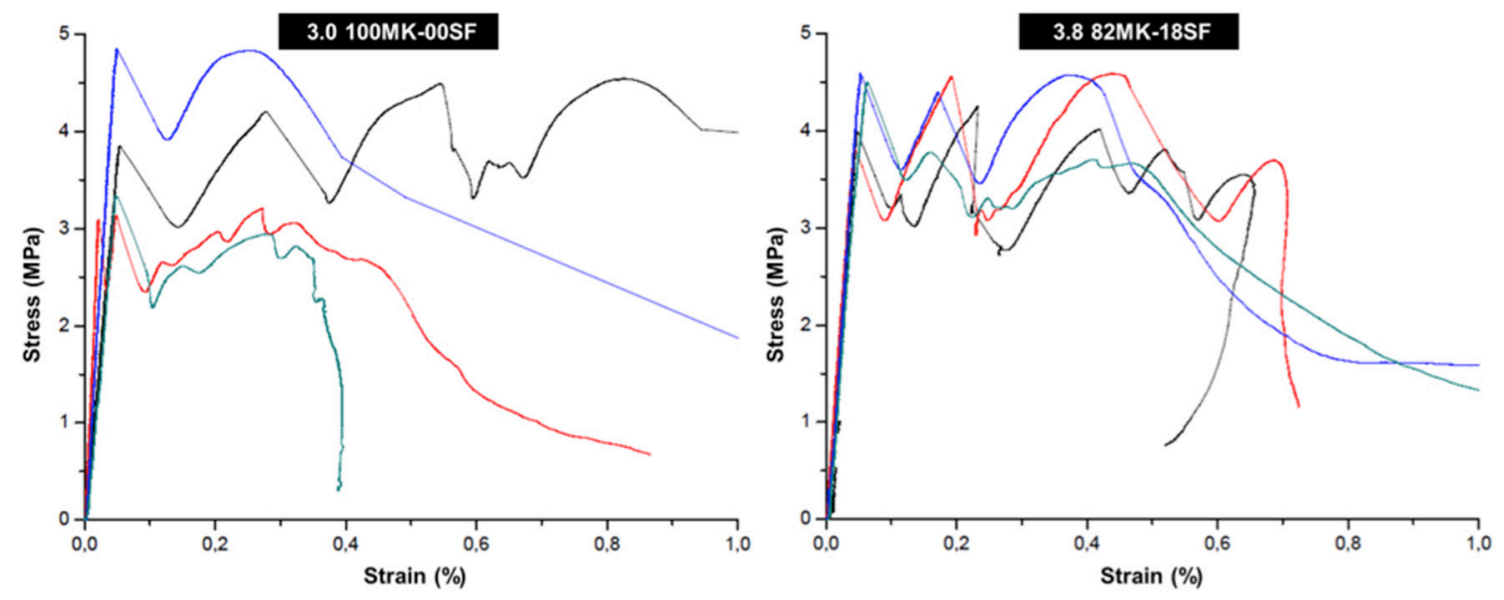

FIGURE 10 | Stress (MPa) $\times$ Strain (\%) curves obtain in direct tension tests for composites with different $\mathrm{SiO}_{2} / \mathrm{Al}_{2} \mathrm{O}_{3}$ ratios.

TABLE 5 | Design parameters related to the micromechanical modeling criteria.

\begin{tabular}{|c|c|c|c|c|c|c|}
\hline Formulation & $\sigma_{0}(\mathrm{MPa})$ & $\sigma_{c c}(\mathrm{MPa})$ & $J_{b}^{\prime}\left(J / m^{2}\right)$ & $J_{\text {tip }}\left(\mathrm{J} / \mathrm{m}^{2}\right)$ & $\mathrm{PSH}_{\text {tension }}\left(\sigma_{0} / \sigma_{\mathrm{cc}}\right)$ & PSHenergy $\left(\mathrm{J}_{\mathrm{b}}^{\prime} / \mathrm{J}_{\text {tip }}\right)$ \\
\hline $3.0100 \mathrm{MK}-00 \mathrm{SF}$ & $1.88(0.68)$ & $3.78(0.78)$ & $5.31(3.85)$ & 31.04 (2.38) & 0.50 & 0.17 \\
\hline 3.8 82MK-18SF & $2.14(0.67)$ & $4.22(0.38)$ & $9.67(6.67)$ & 31.73 (3.94) & 0.51 & 0.30 \\
\hline
\end{tabular}

of cracks (in that case values of $\mathrm{PSH}_{\text {energy }}=\mathrm{J}_{\mathrm{b}}^{\prime} / \mathrm{J}_{\text {tip }}>2.7$ and $\mathrm{PSH}_{\text {tension }}=\sigma_{0} / \sigma_{\mathrm{cc}}>1.3$ were used), the critical fiber volume $\left(V_{f}\right)$ to be used decreases with the increase of the frictional stress $\left(\tau_{0}\right)$. However, when this tension is too high, fiber breaking prevails over slipping, which is a not desired condition. On the other hand, low $\tau_{0}$ values are usually associated with low values of adhesional tension between fiber and matrix, causing a decrease in complementary energy $\left(\mathrm{J}_{\mathrm{b}}^{\prime}\right)$. Therefore, in order to meet both performance indexes ( $\mathrm{PSH}_{\text {tension }}$ and $\mathrm{PSH}_{\text {energy }}$ ) requirements, it would be necessary to increase the volume of fibers to about $9 \%$.

The employment of such high fiber volume is both economically and experimentally infeasible; therefore, another possible approach is to adjust the matrix properties. In this case, it is possible to reduce the fracture toughness of the matrix or to previously induce defects in the composite to control the distribution of cracks. The first scenario is easily executable by increasing the amount of water or adjusting the amount of aggregates used in the composite production. The second alternative requires the introduction of artificial defects in the matrix with a previously defined and controlled distribution, which is more difficult to achieve in practice (Nematollahi et al., 2017). In fact, some strain-hardening AAM related in the literature (Ohno and Li, 2014; Nematollahi et al., 2015) were produced with higher amount of water than the one employed in the AAM produced for this paper; consequently, these composites have lower values of $J_{\text {tip }}$ than those obtained herein $\left(31.04\right.$ and $\left.31.73 \mathrm{~J} / \mathrm{m}^{2}\right)$. In addition, those researches tend to use lower aggregate to binder content $(0.3: 1)$ than those employed in this paper $(1: 1)$, or even suppress the use of aggregates (studies with alkali-activated pastes), which implies in the reduction of $\mathrm{K}_{\mathrm{m}}$ and, consequently, of $\mathrm{J}_{\text {tip }}$. Nevertheless, at
TABLE 6 | Amount of silicate used and toughness obtained in each formulation.

\begin{tabular}{lcc}
\hline Formulation & $\begin{array}{c}\text { Mass of sodium silicate/volume of } \\
\text { AAM }\left[\mathbf{k g} / \mathbf{m}^{\mathbf{3}}\right]\end{array}$ & Toughness (J) \\
\hline 3.0 100MK-00SF & 446.51 & 3.11 \\
3.0 96MK-04SF & 361.48 & 2.69 \\
3.0 93MK-07SF & 295.11 & 3.41 \\
3.8 91MK-09SF & 519.12 & 7.32 \\
3.8 88MK-12SF & 453.75 & 6.57 \\
3.8 85MK-15SF & 385.74 & 6.37 \\
3.8 82MK-18SF & 314.91 & 8.38 \\
\hline
\end{tabular}

this point it is important to note that this is not an economically feasible approach when it comes to engineering materials.

Thus, the simplest strategies to try to adapt the studied composites to SHCC design criteria would be to increase the $\left[\mathrm{H}_{2} \mathrm{O}\right] /\left[\mathrm{Na}_{2} \mathrm{O}\right]$ molar ratio adopted. However, this approach only impacts the value of $\mathrm{PSH}_{\text {energy, }}$ and it is necessary to adopt some other strategy to optimize $\mathrm{PSH}_{\text {tension. }}$ An increase in the $\left[\mathrm{H}_{2} \mathrm{O}\right] /\left[\mathrm{Na}_{2} \mathrm{O}\right]$ molar option is also undesirable with regards to durability aspects.

In this case, increasing the fiber embedment length in the matrix, with the use of fibers with a longer length (e.g., $12 \mathrm{~mm}$ ), could contribute to the increase of $\tau_{0}$ and $\delta_{0}$, representing a feasible approach to increase the values of $J_{\mathrm{b}}^{\prime}$ and of $\sigma_{0}$, in order to obtain higher values for the $\mathrm{PSH}_{\text {energy }}$ and $\mathrm{PSH}_{\text {tension }}$ indexes.

Moreover, the values of $\left[\mathrm{SiO}_{2}\right] /\left[\mathrm{Al}_{2} \mathrm{O}_{3}\right]$ molar ratios adopted by the studies described in the literature corroborate the finding that higher ratios are preferred when the production 
of composites with higher deformation capability is desired. It is well known that one of the ways to reduce the matrix fracture toughness is by reducing its mechanical strength and, as pointed out in this research, the mechanical strength of the metakaolin based AAM seems to be strongly related to the $\left[\mathrm{SiO}_{2}\right] /\left[\mathrm{Al}_{2} \mathrm{O}_{3}\right]$ ratio.

Thus, another possible approach to optimize the properties of the matrix would be to increase even more the $\left[\mathrm{SiO}_{2}\right] /\left[\mathrm{Al}_{2} \mathrm{O}_{3}\right]$ ratio of the studied composites (higher than 3.8), thus reducing their mechanical strength and the $\sigma_{\mathrm{cc}}$ values and increasing the $\mathrm{PSH}_{\text {tension }}$ value. Alternatively, it is also possible to evaluate composites activated with alkaline solution composed only of $\mathrm{NaOH}$, considering that this activator produce AAM with lower mechanical performance but with better workability; this option would reduce $\sigma_{c c}$ and still make it possible to improve the fiber dispersion capability and the incorporation of larger fiber volume, if desired. $\mathrm{NaOH}$-based AAM cured at ambient temperature, however, are very prone to surface efflorescence (formation of $\mathrm{Na}_{2} \mathrm{CO}_{3}$ ), which is also undesirable. Therefore, the production of MK-based SHCC appear to be quite challenging since it will imply on the reduction of the aggregates to binder ratio (higher costs) and/or lower durability (increase in water content).

\section{Environmental Analysis}

Regarding the development of environmentally-friendly composites, Table 6 presents the amount of SS employed in each formulation (in $\mathrm{kg}$ of $\mathrm{SS} / \mathrm{m}^{3}$ of AAM) and the corresponding toughness in flexion, in Joules. When comparing composites 3.0 $100 \mathrm{MK}-00 \mathrm{SF}$ and $82 \mathrm{MK}-18 \mathrm{SF}$, it is possible to notice that even with a reduction of $131.60 \mathrm{~kg}$ of SS per $\mathrm{m}^{3}$ of AAM, toughness of the composite is improved by 5.27 J (i.e., $29.47 \%$ less SS is used and a gain of $169.68 \%$ in the toughness performance of the material is observed).

For a fixed $\left[\mathrm{SiO}_{2}\right] /\left[\mathrm{Al}_{2} \mathrm{O}_{3}\right]$ it is still possible to reduce $\mathrm{SS}$ and improve the toughness: $33.91 \%$ less SS with corresponding $9.66 \%$ rise in toughness for $\left[\mathrm{SiO}_{2}\right] /\left[\mathrm{Al}_{2} \mathrm{O}_{3}\right]=3.0 ; 39.34 \%$ less SS with an increase of $14.45 \%$ in toughness for $\left[\mathrm{SiO}_{2}\right] /\left[\mathrm{Al}_{2} \mathrm{O}_{3}\right]=3.8$.

\section{CONCLUDING REMARKS}

The employment of SF in the alkali-activated composites does not seem to affect their consistency. What appears to be governing the consistency is the value of the $\left[\mathrm{SiO}_{2}\right] /\left[\mathrm{Al}_{2} \mathrm{O}_{3}\right]$ molar ratio of the matrix, with the highest indices (spreading) observed for mortars with $\left[\mathrm{SiO}_{2}\right] /\left[\mathrm{Al}_{2} \mathrm{O}_{3}\right]=3.8$.

In terms of mechanical performance, the compressive strength, flexural strength, and modulus of elasticity of the AAM significantly change neither with the alteration of the $\left[\mathrm{SiO}_{2}\right] /\left[\mathrm{Al}_{2} \mathrm{O}_{3}\right]$ molar ratio nor with the increase of the

\section{REFERENCES}

American Society For Testing Materials (2002). ASTM C293 - 02. Standard Test Method for Flexural Strength of Concrete (Using Simple Beam With CenterPoint Loading. percentage of SF present in the system, i.e., with consequent reduction of the $\left[\mathrm{SiO}_{2}\right]_{-} \mathrm{SS} /\left[\mathrm{Na}_{2} \mathrm{O}\right]_{\text {sol. }}$ in the activating solutions. It can be inferred, therefore, that SF is effectively reacting in these systems; its employment satisfactorily reduce the demand of SS as source of $\mathrm{SiO}_{2}$ without jeopardizing the mechanical performance.

All the produced mortars present deflection-hardening behavior in flexion. However, the deflection capacity is higher for composites with $\left[\mathrm{SiO}_{2}\right] /\left[\mathrm{Al}_{2} \mathrm{O}_{3}\right]$ molar ratio equal to 3.8 , compared to those with $\left[\mathrm{SiO}_{2}\right] /\left[\mathrm{Al}_{2} \mathrm{O}_{3}\right]=3.0$. Neither the amount of SF employed nor the $\left[\mathrm{SiO}_{2}\right]_{-} \mathrm{SS} /\left[\mathrm{Na}_{2} \mathrm{O}\right]_{-}$sol. molar ratio or the solution to binder ratio seems to affect the toughness behavior of the composites. The parameter that appears to be governing toughness is the overall $\left[\mathrm{SiO}_{2}\right] /\left[\mathrm{Na}_{2} \mathrm{O}\right]$ ratio in the activator, regardless of the soluble silica source (SF or SS). Therefore, the employment of SF as precursor is not detrimental to the toughness performance of MK-based alkaliactivated composites.

There was no significant variation in apparent dry density, water absorption or apparent porosity between all composites, and this implies that the durability properties will not be affected if less SS is employed in the design of fiber-reinforced alkaliactivated composites, as long as the water content is kept constant (herein in terms of $\left[\mathrm{H}_{2} \mathrm{O}\right] /\left[\mathrm{Na}_{2} \mathrm{O}\right]$ molar ratio). The composites developed in this study did not present the strain-hardening behavior, but rather deflection-hardening properties with multi cracking development in flexion. All results presented in the paper indicate that the employment of SF as an alternative precursor can provide MK-based alkali-activated composites with satisfactory physical, mechanical and durability properties, as well as enable the development of binders with lower environmental impact (lower SS demand). The cost reduction (not assessed here) will depend on local availability and costs of the main raw materials, i.e., MK, SF and SS and may vary from one country to another.

\section{AUTHOR CONTRIBUTIONS}

$\mathrm{RB}, \mathrm{PB}$, and FS conceived and designed the analysis. $\mathrm{RB}$ and AT collected the data. RB performed the analysis and wrote the paper.

\section{ACKNOWLEDGMENTS}

The authors would like to thank CNPq, CAPES, FAPEMIG, and CEFET-MG for supporting this research, as well as the companies Kuraray Co. Ltd. (Japan), Metacaulim do Brasil Ltda. (Brazil), Moinhos Gerais Ltda. (Brazil) and Tecnosil Construction Materials (Brazil), which donated raw materials to the research group. 
Associação Brasileira de Normas Técnicas (2017). NBR 8522 - Concreto - Determinação dos Módulos Estáticos de Elasticidade e de Deformação à Compressão.

Bajza, A., Rouseková, I., and Živica, V. (1998). Silica fumesodium hydroxide binding systems. Cem. Concr. Res. 28, 13-18. doi: 10.1016/S0008-8846(97)00192-0

Bakharev, T., Sanjayan, J., and Cheng, Y.-B. (2003). Resistance of alkaliactivated slag concrete to acid attack. Cem. Concr. Res. 33, 1607-1611. doi: 10.1016/S0008-8846(03)00125-X

Bakharev, T., Sanjayan, J. G., and Cheng, Y.-B. (2001a). Resistance of alkaliactivated slag concrete to alkali-aggregate reaction. Cem. Concr. Res. 31, 331-334. doi: 10.1016/S0008-8846(00)00483-X

Bakharev, T., Sanjayan, J. G., and Cheng, Y.-B. (2001b). Resistance of alkaliactivated slag concrete to carbonation. Cem. Concr. Res. 31, 1277-1283. doi: 10.1016/S0008-8846(01)00574-9

Bakharev, T., Sanjayan, J. G., and Cheng, Y.-B. (2002). Sulfate attack on alkali-activated slag concrete. Cem. Concr. Res. 32, 211-216. doi: 10.1016/S0008-8846(01)00659-7

Bentur, A., and Mindess, S. (2007). Fibre Reinforced Cementitious Composites. 2nd $E d n$. London: CRC Press; Taylor and Francis.

Bernal, S. A., Krivenko, P. V., Provis, J. L., Puertas, F., Rickard, W. D. A., Shi, C., et al. (2014) "Other potential applications for alkali-activated materials," in Alkali Activated Materials. RILEM State-of-the-Art Reports, Vol. 13. eds J. Provis and J. van Deventer (Dordrecht: Springer), 339-379. doi: 10.1007/978-94-007-7672-2_12

Bernal, S. A., Rodríguez, E. D., Mejia de Gutiérrez, R., Provis, J. L., and Delvasto, S. (2012). Activation of metakaolin/slag blends using alkaline solutions based on chemically modified silica fume and rice husk ash. Waste Biomass Valorization 3, 99-108. doi: 10.1007/s12649-011-9093-3

Bhutta, A., Borges, P. H. R., and Banthia, N. (2016). "Mechanical properties Mk-based geopolymer composites reinforced with," in Proceedings of the 9th Rilem International Symposium on Fiber Reinforced Concrete (BEFIB 2016) (Vancouver, BC).

Bondar, D., Lynsdale, C. J., Milestone, N. B., Hassani, N., and Ramezanianpour, A. A. (2010). "Engineering properties of alkali activated natural pozzolan concrete," in Proceedings of the Second International Conference on Sustainable Construction Materials and Technologies, eds J. Zachar, P. Claisse, T. R. Naik, and E. Ganjian (Ancona: Università Politecnica delle Marche), 1093-1102. Available online at: http://www.claisse.info/2010\%20papers/m42.pdf

Borges, P. H. R., Bhutta, A., Bavuzo, L. T., and Banthia, N. (2017). Effect of $\mathrm{SiO} 2 / \mathrm{Al} 2 \mathrm{O} 3$ molar ratio on mechanical behavior and capillary sorption of MKbased alkali-activated composites reinforced with PVA fibers. Mater. Struct. 50, 1-12. doi: 10.1617/s11527-017-1021-y

Borges, P. H. R., de Lourenço, T. M. F., Foureaux, A. F. S., and Pacheco, L. S. (2014). Estudo comparativo da análise de ciclo de vida de concretos geopoliméricos e de concretos à base de cimento Portland composto (CP II). Ambient. Construído 14, 153-168. doi: 10.1590/S1678-86212014000 200011

Davidovits, J. (1994). "Properties of geopolymer cements," in Proceedings of the First international Conference on Alkaline Cements and Concretes (Kiev: Scientific Research Institute on Binders and Materials), 131-149.

Duxson, P., Fernández-Jiménez, A., Provis, J. L., Lukey, G. C., Palomo, A., and Van Deventer, J. S. J. (2007). Geopolymer technology: the current state of the art. J. Mater. Sci. 42, 2917-2933. doi: 10.1007/s10853-006-0637-z

Duxson, P., Lukey, G. C., Separovic, F., and Van Deventer, J. S. J. (2005). Effect of alkali cations on aluminum incorporation in geopolymeric gels. Ind. Eng. Chem. Res. 44, 832-839. doi: 10.1021/ie0494216

Garcia-Lodeiro, I., Palomo, A., and Fernández-Jiménez, A. (2015). "Crucial insights on the mix design of alkali-activated cement-based binders," in Handbook of Alkali-Activated Cements, Mortars and Concretes, eds F. PachecoTorgal, J. A. Labrincha, C. Leonelli, A. Palomo, and P. Chindaprasirt (Oxford: Woodhead Publishing), 49-73. doi: 10.1533/9781782422884.1.49

Juenger, M. C. G., Winnefeld, F., Provis, J. L., and Ideker, J. H. (2011). Advances in alternative cementitious binders. Cem. Concr. Res. 41, 1232-1243. doi: 10.1016/j.cemconres.2010.11.012

Kamseu, E., Beleukà Moungam, L. M., Cannio, M., Billong, N., Chaysuwan, D., Melo, U. C., et al. (2017). Substitution of sodium silicate with rice husk ash- $\mathrm{NaOH}$ solution in metakaolin based geopolymer cement concerning reduction in global warming. J. Clean. Prod. 142, 3050-3060. doi: 10.1016/j.jclepro.2016.10.164

Kanda, T., and Li, V. C. (2006). Practical design criteria for saturated pseudo strain hardening behavior in ECC. J. Adv. Concr. Technol. 4, 59-72. doi: $10.3151 /$ jact.4.59

Komljenović, M. (2015). "Mechanical strength and Young's modulus of alkaliactivated cement-based binders," in Handbook of Alkali-Activated Cements, Mortars and Concretes, eds F. Pacheco-Torgal, J. A. Labrincha, C. Leonelli, A. Palomo, and P. Chindaprasirt (Oxford: Woodhead Publishing), 171-215. doi: 10.1533/9781782422884.2.171

Komnitsas, K. A. (2011). Potential of geopolymer technology towards green buildings and sustainable cities. Proced. Eng. 21, 1023-1032. doi: $10.1016 /$ j.proeng.2011.11.2108

Kong, D. L. Y., and Sanjayan, J. G. (2008). Damage behavior of geopolymer composites exposed to elevated temperatures. Cem. Concr. Compos. 30, 986-991. doi: 10.1016/j.cemconcomp.2008.08.001

Kong, D. L. Y., Sanjayan, J. G., and Sagoe-Crentsil, K. (2007). Comparative performance of geopolymers made with metakaolin and fly ash after exposure to elevated temperatures. Cem. Concr. Res. 37, 1583-1589. doi: 10.1016/j.cemconres.2007.08.021

Lee, B. Y., Cho, C.-G., Lim, H.-J., Song, J.-K., Yang, K.-H., and Li, V. C. (2012). Strain hardening fiber reinforced alkali-activated mortar - A feasibility study. Constr. Build. Mater. 37, 15-20. doi: 10.1016/j.conbuildmat.2012.06.007

Li, V. C., and Leung, C. K. Y. (1992). Steady-state and multiple cracking of short random fiber composites. J. Eng. Mech. 118, 2246-2264. doi: 10.1061/(ASCE)0733-9399(1992)118:11(2246)

Li, V. C., Wang, S., and Wu, C. (2001). Tensile strain-hardening behavior of polyvinyl alcohol engineered cementitious composite (PVA-ECC). ACI Mater. J. 98, 233-268. doi: 10.14359/10851

Li, V. C., Wu, C., Wang, S., Ogawa, A., and Saito, T. (2002). Interface tailoring for strain-hardening Polyvinyl Alcohol-engineered cementitious composite (PVA-ECC). ACI Mater. J. 99, 463-472. doi: 10.14359/12325

Li, Z., Zhang, Y., and Zhou, X. (2005). Short fiber reinforced geopolymer composites manufactured by extrusion. J. Mater. Civ. Eng. 17, 624-631. doi: 10.1061/(ASCE)0899-1561(2005)17:6(624)

Lloyd, N. A., and Rangan, B. V. (2010). "Geopolymer concrete: a review of development and opportunities," in Proceedings of the 35th Conference on Our World in Concrete and Structures (Singapore: CI-Premier PTE LTD). Available online at: https://pdfs.semanticscholar.org/1049/ 5b9901443d533445ddd6e5adcab449597742.pdf (accessed on December 01, 2017).

Mechtcherine, V., Silva, F., de, A., Butler, M., Zhu, D., Mobasher, B., et al. (2011). Behaviour of strain-hardening cement-based composites under high strain rates. J. Adv. Concr. Technol. 9, 51-62. doi: 10.3151/jact.9.51

Nematollahi, B., Qiu, J., Yang, E.-H., and Sanjayan, J. (2017). Micromechanics constitutive modelling and optimization of strain hardening geopolymer composite. Ceram. Int. 43, 5999-6007. doi: 10.1016/j.ceramint.2017.01.138

Nematollahi, B., Sanjayan, J., and Shaikh, F. U. A. (2014). Comparative deflection hardening behavior of short fiber reinforced geopolymer composites. Constr. Build. Mater. 70, 54-64. doi: 10.1016/j.conbuildmat.2014.07.085

Nematollahi, B., Sanjayan, J., and Shaikh, F. U. A. (2015). Tensile strain hardening behavior of PVA fiber-reinforced engineered geopolymer composite. J. Mater. Civ. Eng. 27, 1-12. doi: 10.1061/(ASCE)MT.1943-5533.0001242

Němeček, J., Šmilauer, V., and Kopecký, L. (2011). Nanoindentation characteristics of alkali-activated aluminosilicate materials. Cem. Concr. Compos. 33, 163-170. doi: 10.1016/j.cemconcomp.2010.10.005

Obonyo, E., Kamseu, E., Melo, U. C., and Leonelli, C. (2011). Advancing the use of secondary inputs in geopolymer binders for sustainable cementitious composites: a review. Sustainability 3, 410-423. doi: 10.3390/su3020410

Ohno, M., and Li, V. C. (2014). A feasibility study of strain hardening fiber reinforced fly ash-based geopolymer composites. Constr. Build. Mater. 57, 163-168. doi: 10.1016/j.conbuildmat.2014.02.005

Oliveira, A. M. (2015). Fluência a Altas Temperaturas, Aderência Fibra-Matriz E Comportamento Mecânico Sob Ações Higrotérmicas De Compósitos Cimentícios Reforçados Com Fibras De Pva. Available online at: http://www.coc.ufrj.br/pt/ teses-de-doutorado/390-2015/4605-andrielli-morais-de-oliveira

Pacheco-Torgal, F., Jalali, S., and Castro Gomes, J. P. (2009). "Utilization of mining wastes to produce geopolymer binders," in Geopolymers: Structure, 
Processing, Properties and Industrial Applications, eds J. L. Provis and J. S. J. Van Deventer (Cambridge: Woodhead Publishing Limited), 267-293. doi: $10.1533 / 9781845696382.2 .267$

Provis, J. L., Bílek, V., Buchwald, A., Dombrowski-Daube, K., and Varela, B. (2014). "Durability and testing-physical processes," in Alkali Activated Materials. RILEM State-of-the-Art Reports, Vol. 13. eds J. Provis and J. van Deventer (Dordrecht: Springer), 277-307. doi: 10.1007/978-94-007-7672-2_10

Provis, J. L., Duxson, P., Van Deventer, J. S. J., and Lukey, G. C. (2005). The role of mathematical modelling and gel chemistry in advancing geopolymer technology. Chem. Eng. Res. Des. 83, 853-860. doi: 10.1205/cherd.04329

Provis, J. L., Yong, S. L., and Duxson, P. (2009). "Nanostructure/microstructure of metakaolin geopolymers," in Geopolymers: Structure, Processing, Properties and Industrial Applications, eds J. L. Provis and J. S. J. Van Deventer (Cambridge: Woodhead Publishing Limited), 72-88. doi: 10.1533/9781845696382.1.72

Puertas, F., Amat, T., Fernández-Jiménez, A., and Vázquez, T. (2003). Mechanical and durable behaviour of alkaline cement mortars reinforced with polypropylene fibres. Cem. Concr. Res. 33, 2031-2036. doi: $10.1016 / 50008-8846(03) 00222-9$

Puertas, F., and Torres-Carrasco, M. (2014). Use of glass waste as an activator in the preparation of alkali-activated slag. Mechanical strength and paste characterisation. Cem. Concr. Res. 57, 95-104. doi: 10.1016/j.cemconres.2013.12.005

Redon, C., Li, V. C., Wu, C., Hoshiro, H., Saito, T., and Ogawa, A. (2001). Measuring and modifying interface properties of PVA fibers in ECC matrix. J. Mater. Civil Eng. 13, 399-406. doi: 10.1061/(asce)0899-1561(2001)13:6(399)

RILEM (1984). CPC 11.3. Absorption d'eau par immersion sous vide [Absorption of water by immersion under vacuum]. Matér. Constr. 17, 391-394. doi: $10.1007 /$ BF02478713

RILEM (1990). RILEM Draft Recommendation TC 89-FMT (Fracture Mechanics of Concrete - Test Methods): determination of fracture parameters of plain concrete using three-point bend tests. Mater. Struct. 23, 457-460. doi: 10.1007/B. F.02472029

Rodríguez, E. D., Bernal, S. A., Provis, J. L., Paya, J., Monzo, J. M., and Borrachero, M. V. (2013). Effect of nanosilica-based activators on the performance of an alkali-activated fly ash binder. Cem. Concr. Compos. 35, 1-11. doi: 10.1016/j.cemconcomp.2012.08.025

Rouseková, I., Bajza, A., and Živica, V. (1997). Silica fume-basic blast furnace slag systems activated by an alkali silica fume activator. Cem. Concr. Res. 27, 1825-1828. doi: 10.1016/S0008-8846(97)00191-9

Sakulich, A. R. (2011). Reinforced geopolymer composites for enhanced material greenness and durability. Sustain. Cities Soc. 1, 195-210. doi: 10.1016/j.scs.2011.07.009

Shaikh, F. U. A. (2013). Deflection hardening behaviour of short fibre reinforced fly ash based geopolymer composites. Mater. Des. 50, 674-682. doi: 10.1016/j.matdes.2013.03.063
Stavrinides, G. (2010). Alternative Cements in Concrete Construction: Assessment, Prospects and Commercialisation Strategies. MSc. Thesis, University College London (London).

Tchakouté, H. K., Rüscher, C. H., Kong, S., Kamseu, E., and Leonelli, C. (2016). Geopolymer binders from metakaolin using sodium waterglass from waste glass and rice husk ash as alternative activators: a comparative study. Constr. Build. Mater. 114, 276-289. doi: 10.1016/j.conbuildmat.201 6.03.184

Torres-Carrasco, M., and Puertas, F. (2015). Waste glass in the geopolymer preparation. Mechanical and microstructural characterisation. J. Clean. Prod. 90, 397-408. doi: 10.1016/j.jclepro.2014.11.074

Vafaei, M., and Allahverdi, A. (2017). High strength geopolymer binder based on waste-glass powder. Adv. Powder Technol. 28, 215-222. doi: 10.1016/j.apt.2016.09.034

Van Deventer, J. S. J., Provis, J. L., Duxson, P., and Brice, D. G. (2010). Chemical research and climate change as drivers in the commercial adoption of alkali activated materials. Waste Biomass Valorization 1, 145-155. doi: 10.1007/s12649-010-9015-9

Wang, S., and Li, V. C. (2007). Engineered cementitious composites with high-volume fly ash. ACI Mater. J. 104, 233-241. doi: 10.14359/ 18668

Ye, H., Cartwright, C., Rajabipour, F., and Radlinska, A. (2017). Understanding the drying shrinkage performance of alkali-activated slag mortars. Cem. Concr. Compos. 76, 13-24. doi: 10.1016/j.cemconcomp.2016. 11.010

Živica, V. (1999). Possibilities of a novel use of silica fume in mineral binding systems. Constr. Build. Mater. 13, 271-277. doi: 10.1016/S0950-0618(99)00028-8

Živica, V. (2004). High effective silica fume alkali activator. Bull. Mater. Sci. 27, 179-182. doi: 10.1007/BF02708502

Živica, V. (2006). Effectiveness of new silica fume alkali activator. Cem. Concr. Compos. 28, 21-25. doi: 10.1016/j.cemconcomp.2005. 07.004

Conflict of Interest Statement: The authors declare that the research was conducted in the absence of any commercial or financial relationships that could be construed as a potential conflict of interest.

Copyright (c) 2019 Batista, Trindade, Borges and Silva. This is an open-access article distributed under the terms of the Creative Commons Attribution License (CC BY). The use, distribution or reproduction in other forums is permitted, provided the original author(s) and the copyright owner(s) are credited and that the original publication in this journal is cited, in accordance with accepted academic practice. No use, distribution or reproduction is permitted which does not comply with these terms. 